\title{
Inverse Relationship of Orally-Based Noetic Processing and Skeuomorphic Formulaicity in the Middle English 'Matter of England' Verse Romances
}

\section{Relación inversa del procesamiento noético de base oral y la formulaicidad esqueuomórfica en los romances en verso en inglés medio sobre la materia de Inglaterra}

JOHN C. FORD

Institut National Universitaire Jean-François Champollion

Place Verdun

81012 Albi, France

john.ford@univ-jfc.fr

Orcid ID 0000-0002-2890-2757

\begin{abstract}
The Middle English verse romances of the thirteenth and fourteenth centuries have frequently been referenced as exemplifying the formulaicity associated with orality in medieval transitional texts. This is as true when counting formulae of the Parry-Lord variety according their theory of oral-formulaic composition as it is when counting the more flexibly defined formulaic expressions of the sort permitted under the theory of oral traditionalism. Both methods, however, probably give an inflated view of the extent to which orally-based thinking was involved in composition of the romances, since they focus exclusively on the formulaic surface-structure expressions which do not always accurately reflect deep-structure ideas or frames of thought. The present concise examination of the Matter of England romances - a subset of the Middle English verse romances spanning the lifetime of the genre - suggests that, contrary to what one might expect, the number, length and complexity
\end{abstract}

of such formulaic expressions actually appear to increase as evidence of purely orally-based thought declines. This finding is realized by briefly measuring the extent to which each romance instantiates Walter Ong's nine psychodynamic characteristics of orally based thought and expression, five of which concern the deep-structure frames of the former with the remaining four concerned with the surface-structure scripts of the latter. It then concludes by proposing that the much-vaunted residual traces of orality in the formulaic expressions are not so much true reflections of orally-based thinking as they are contrived literary 'skeuomorphs' masquerading as such in order to lend the tales credibility and authenticity.

Keywords: Transitional Texts. Orality and Literacy. Middle English Verse Romance. Matter of England: King Horn, Havelok, Athelston, Gamelyn. Romance Fund. Formulaic Expression. Literary Skeuomorphs. 
Resumen: Los romances en verso del inglés medio de los siglos XIII y XIV suelen mencionarse como ejemplos de la formulación asociada con la oralidad en los textos de transición medievales. Esto es cierto tanto cuando se cuentan las fórmulas de la variedad Parry-Lord según su teoría de la composición oral-formulaica como cuando se cuentan las expresiones formulares de manera más flexible tal como permite la teoría del tradicionalismo oral. Sin embargo, es probable que ambos métodos den una visión exagerada del grado en que el pensamiento oral estuvo involucrado en la composición de los romances, ya que se centran exclusivamente en las expresiones de estructura formular superficial que no siempre reflejan con precisión ideas o marcos de estructura profunda de pensamiento. El presente breve examen de los romances de la materia de Inglaterra -un subconjunto de los romances en verso del inglés medio, que abarcan toda la historia del género- sugiere que, al contrario de lo que cabría esperar, el número, la longitud y la complejidad de tales expresiones formulares en realidad parecen aumentar a medida que la evidencia del pensamiento puramente oral disminuye. Este hallazgo resulta de medir sucintamente el grado en que cada romance ejemplifica las nueve características psicodinámicas que Walter Ong atribuye al pensamiento y la expresión de base oral, cinco de las cuales se refieren a los marcos de estructura profunda del primero mientras que las cuatro restantes se relacionan con los guiones de estructura superficial de la segunda. Como conclusión, se propone que los rastros residuales de oralidad en las expresiones formuladas son menos reflejos auténticos del pensamiento basado en la oralidad que 'esqueuomorfos' literarios inventados como tales para dar credibilidad y autenticidad a los cuentos.

Palabras clave: Textos de transición. Oralidad y escritura. Romances en verso ingleses medievales. Materia de Inglaterra: King Horn, Havelok, Athelston, Gamelyn. Repertorio de romance. Expresión formulaica. Esqueumorfismo literario.

\section{INTRODUCTION}

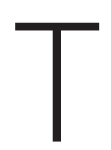
he Middle English verse romances of the thirteenth and fourteenth century were arguably the first significant revival of English letters after several centuries of domination in all domains of serious scholarly or cultural discourse by French and Latin. This also happened to be the period of transition from the High to the Late Middle Ages throughout Europe, characterized across the continent by a societal shift that began to subordinate traditional oral habits to more literate ones in all aspects of public life, including government, law, communal memory and entertainment. England was no exception, with the legal reforms initiated by Edward I around the turn of the century providing a prime example. Increasing codification of law gave statutes ascendancy over consuetudinary oral tradition; land held since time immemorial suddenly required written charters to prove ownership; and the diffusion of royal proclamations throughout the kingdom by writ meant that soon 'literate modes were familiar even to serfs' (Clanchy 2).

Such was the backdrop against which the medieval verse romances were produced in vernacular English - at the time, a third-rate language for the country's third estate, ranking below both the French of Norman aristocrats and Latin of the clergy. These self-assuredly unpolished versions of romance 
were intended for the common folk rather than the courtly, or - as Chaucer might put it - the lewed [uneducated] rather than learned. It is therefore not surprising that scholars of medieval English literature have frequently sought to find traces of orality in this popular genre, and their criteria for evaluation has traditionally produced satisfyingly high estimates. This is as true of the rigidly defined formula of the classic Parry-Lord theory of 'oral-formulaic composition' as it is for the more flexible formulaic expressions permitted under later 'oral traditionalism'. ${ }^{1}$ Indeed, oral traditionalism largely grew out of dissatisfaction amongst medievalists over the failure of the rigid Parry-Lord definition of a formula to encompass all examples of what they considered to be formulaic in various vernacular literatures. ${ }^{2}$ Today - and despite Lord's early misgivings, later softened somewhat, which prescribed a binary 'Great Divide' separating the literate from the oral - all such writings would be recognized as 'transitional texts', for reasons explained by Finnegan (this volume), in that they show the signs of having been produced by societies making the slow transition from orality to literacy.

By their very natures, however, both approaches undoubtedly give somewhat skewed results in measuring the degree to which oral thought was actually involved in the creation of such texts, since each only analyses the most

1. In order to address the Homeric Question, Milman Parry first defined the formula as 'a group of words which is regularly employed under the same metrical conditions to express a given essential idea' $(1930,80)$. After his untimely death, his work was continued by his protégé, Albert Lord, whose studies of illiterate Balkan bards helped confirm many of Parry's hypotheses. This led to the formalization of the Parry-Lord theory of 'oral-formulaic' construction in Lord's 1960 The Singer of Tales. Although it would be impossible to provide an exhaustive list, some influential early studies that recognized a high degree of orality in the romances under the ParryLord approach of 'structuralist folktale analysis' (Kabir 19), especially those dealing with works here concerned, include: Crosby 1936, 105-10; Crosby 1938, 430; Baugh 1950; 1967, 10; Hanning; Wittig 24-5. More generally, Bradbury (1993) provides a list of similarly inclined 'Continental historians and literary scholars concerned with recovering the orally-transmitted culture of earlier periods' (116).

2. In order for the definition to recognize all occurrences of formulaic diction in his studies of the Chanson de Roland, for example, Joseph Duggan adapted the Lord-Parry definition of a formula to: 'a phrase co-extensive with the hemistich and substantially identical with another phrase in the poem' (7); Sarah Kay subsequently revised the definition even further for Raoul de Cambrai, allowing 'some variety in prefixation and inflexion', as well as 'variation in word order', but even then lamented that the definition is 'somewhat stringent' (xl-xli). Robert Diamond had already noted even before the publication of Lord's The Singer of Tales that in Old English 'many formulas consist of a single word' (231). It was the plethora of inconsistencies that ultimately led John Miles Foley, himself a specialist of Old and Middle English, to formalize a more relaxed theory of 'oral traditionalism' - better suited to the transitional texts of medieval literature than the strict Parry-Lord theory of 'oral-formulaicity', and particularly well adapted for medieval English - in his Singer of Tales in Performance. 
conspicuous manifestation of structural reason related to thought, the enunciation of language - specifically the formula, which Lord defined as 'the offspring of the marriage of thought and sung verse' (31) - regardless of whether the utterance is orally or literately produced and recorded. This aspect corresponds to what Noam Chomsky once qualified as the surface structure of linguistic representation (S-structure), which is only the outward syntaxgenerated expression of deeper semantic processes related to meaning (DStructure), where true evidence of the divergent ways in which a literate and an oral mind conceive and handle information differently is to be found. ${ }^{3} \mathrm{Al}-$ though the definitions and utility of these S- and D-structures have been significantly revised if not entirely abandoned (even by Chomsky himself), their original respective conceptualizations are nevertheless useful here, because they are fundamentally consistent with Charles Fillmore's syntactic 'scripts', which attempt to communicated the 'ideational scaffolding' or 'frame' of semantic thought underlying an utterance. More recently, Sarali Gintsburg (2019) has convincingly equated Fillmore's frames and scripts with themes and formulae in the transitional texts of Jebli poetry in a way that has practical applications for the study of such structures in the transitional texts of Middle English verse romance as well. Ultimately, however, the unarticulated and intangible nature of these deep-structure semantic frames or themes renders them imperceptibly elusive, a quality that makes them difficult to measure empirically and objectively. Indeed, even Chomsky lamented that the relative ease with which his S-structure can be perceived and analysed as opposed to its dichotomous partner D-structure is 'unquestionably' the reason why 'modern linguistics is largely confined in scope to the former' (30).

Nevertheless, about the same time Fillmore was developing his theory of frame semantics, Walter Ong was attempting to come to grips with the function of the literate mind in the oral past, postulating various 'psychodynamics of orality' and nine 'further characteristics of orally based thought and expression', namely that they are: 1 ) additive rather than subordinate; 2) aggregative rather than analytic; 3) redundant or 'copious'; 4) conservative or traditionalist; 5) close to the human lifeworld; 6) agonistically toned; 7) empathetic and participatory; 8) homeostatic; and 9) situational rather than abstract (36-55). As

3. Terms related to Chomsky's theory of transformational-generative grammar are use here in a way that is consistent with the manner in which they were described in his original 1962 paper, The Logical Basis of Linguistic Theory, republished in 1964 as Current Issues in Linguistic Theory. 
this examination will show, the first, second, third, and seventh of these relate directly to the way information is expressed to the audience; this syntactical performance is fundamentally just the outward expression of internally formulated ideas, the surface structure onto which deep thoughts are mapped in either oral or written expression. Indeed, they are the criteria that underly the utilization of the repetitive stylized linguistic patterning involved in the creation of formulae or formulaic expression. The fourth, fifth, sixth, eighth and ninth criteria, however, actually seem to be more concerned with how the internal thoughts are conceived, structured and conceptualized semantically; they concern the deep thoughts themselves, which might be handled differently by minds that are orally-processing and those conditioned by literacy.

It seemed worthwhile to assess the degree to which these psychodynamic characteristics of orality occurred together in a sample of the Middle English verse romances, particularly the frequently overlooked features related to deep-structure conceptualization of information. The so-called Matter of England romances appeared to be a particularly useful subset for such a study, as they provide examples that attest to the evolution of the genre over the entire course of the Middle English verse romance's development. These homely romances are more concerned with the exploits of native English or AngloDanish heroes than they are with the Classical heroes of the Matter of Rome, the Celtic myths and Round-Table knights of the Matter of Britain, or Charlemagne's paladins and peers who populate the Matter of France. This cycle also begins at the beginning with the oldest English romance, the earlythirteenth-century King Horn, ${ }^{4}$ and runs through to the late-fourteenthcentury Gamelyn, ${ }^{5}$ written only a scant decade before the genre's death knell was tolled by Chaucer's satirical parody, Sir Thopas (c. 1387). In between come the late-thirteenth-century Havelok the Dane, ${ }^{6}$ usually considered the second

4. King Horn is traditionally dated to 1225 (Herzman, Drake and Salisbury 11), though later dates have been suggested (see Allen). The tale survives in three manuscripts: MS. Harley 2253 at the British Library, London; MS Laud Misc. 108 at the Bodleian Library, Oxford (1300-1325); and MS. Gg. iv. 27. 2 at the Cambridge University Library. It is ostensibly a translation of an AngloNorman Romance of Horn, written by a certain 'Thomas' around 1170 (see Weiss 1).

5. Crane dates Gamelyn as late as 1375 (73), Lindner as early as the thirteenth century (112-13), though most place it somewhere between Skeat's 1340 (38) and Dunn's 1379 (32). A copy having been found among his papers, the tale was spuriously attributed to Chaucer, and appears early in at least 25 manuscripts of The Canterbury Tales.

6. Herzman, Drake and Salisbury date Havelok to the 1280 s, noting that it is probably the reworking of an Anglo-Norman Lai d'Aveloc, of which they provide a summary (73). The unique manuscript version follows Horn in Bodleian MS Laud. 
oldest English romance, and Athelston, ${ }^{7}$ dated to the mid or late fourteenth century, ${ }^{8}$ and thus nearly contemporaneous with Gamelyn. ${ }^{9}$

By separating Ong's characteristic features of orally-based thought and expression into two separate groups and (to the limited extent such an investigation is possible in the space here permitted) probing the degree to which they occur in each of these four Matter of England romances individually, a remarkable finding emerges. While all the romances provide instances of each individual criterion, the second group of features - those dealing with the actual semantic meaning of deep-structure frames or themes - seem to be more prevalent in the earlier romances than the later ones. This is exactly what is to be expected if one follows the logic that the earlier texts are closer to a culture of 'primary orality, the orality of cultures untouched by literacy' (Ong 5). Counterintuitively, however, the first group of characteristically oral features - those which should primarily concern the syntactical representation of deep thoughts in surface-structure scripts, the expressions that an oral mind naturally organizes formulaically - actually seem to be more prevalent in the later romances. It thus appears that just as romancers' more literate minds began internally framing deep-structure information in a way more consistent with writing-dependent thinking, the way in which those thoughts were expressed externally in the formulaic surface-structure scripts of their narratives became more consistent with orally-based expression.

Although such a turn of events might seem illogical, it is not entirely inexplicable if one keeps in mind that not every turn of events is straightforward. It is relatively easy, for example, to formulate surface-structure expressions inconsistent with one's actual deep-structure ideas; after all, who has not carefully adapted information they want to relate in a conscious effort to make its delivery more palatable? As entertainers, romancers would want to do just that, and it seems one way in which they did so was by consciously using speech patterns more consistent with orally-based thought even if their own thoughts were organized more literately. Indeed, the incongruity between the romancers' divergent patterns of thought and expression might explain

7. The only manuscript copy is: MS Caius College Library, Cambridge Ms 175 , fols. 120r-31r.

8. The mid-century date is given by Lambdin (28), while the late date is given by Herzman, Drake and Salisbury (341).

9. It is also noteworthy that - though they are all based unambiguously on folkloric English characters - the first three apparently have written Anglo-Norman antecedents, reflecting the primacy of French even when folktales of Anglo-Saxon or even Anglo-Danish provenance are concerned. 
the oft-noted discrepancy between the way simple, straightforward formulae of primary orality are created and used differently from the often-complex formulaic expressions of oral traditionalism (see, e.g., Kabir; Wittig). It will be argued that such mock formulae simulating oral thinking are ultimately 'literary skeuomorphs', non-essential vestiges of a once essential functional feature. And while they may have been somewhat useful in facilitating performance reading, the primary purpose of such artifices might have been to give listeners or readers the impression that even a new romance was older or more authentic, or simply to meet audience expectations by providing a romance in a recognized, expected form.

\section{PART I: Conceptualization and HANDling of SEMANTIC INFORMation}

For the purposes of this study, in order to better examine the extent and ways in which these romances exhibit Ong's psychodynamic features of orality, it is necessary to rearrange his order somewhat, beginning first with the group of elements related to the way in which semantic meaning is handled (the deepstructure frames or themes), before showing how that information is expressed syntactically (the corresponding surface-structure scripts as formulae). Thus, the second group will be examined first. Within each group, it furthermore becomes necessary to rearrange the order of the individual criteria so that simple elements which have a causative effect on more complex ones are treated first. All this leads one to begin where Ong ends, starting with his ninth criterion of oral literature being 'situational rather than abstract' (a), then in turn treating his fifth, eighth, fourth and sixth criteria in Part I. These elements are respectively labelled (a), (b), (c), (d) and (e) hereafter in this paper. In Part II, the remaining elements will then be examined, beginning with Ong's second element before treating the third, first and finally the seventh, respectively labelled (f), (g), (h) and (i).

\section{I (a): Content is Handled Situationally Rather than Abstractly}

By 'situational rather than abstract', Ong means that language expressing thought demonstrates 'orally based' rather than 'chirographically based noetic processes' (50). Such accounts naturally rely on practical 'situational thinking', itself dependent on 'concrete objects' rather than abstract 'categorical terms' (51). In other words, items are never described by referring to 
their geometrical shape or form, such as saying an item is square or round, but by comparing them to concrete real-world items that instantiate that form, such as a box or a wheel.

King Horn, for example, is full of swords, heads, rings, even fishing lines, but nothing is ever described as long, round or circular. Even a wedding band is identified by its content golde rather than its shape as a ring (1048). ${ }^{10}$ Likewise, the outline of Havelok's distinguishing royal birthmark is never described by its imprecise shape, but as a noble croiz ('noble cross' [1264]). ${ }^{11}$ Reference to real-life items rather than abstract shapes also occurs in Athelston, in which presumed culprits must undergo an ordeal by fire, walking over red-hot plowgh-lengthe ('ploughshares' [571]), ${ }^{12}$ which historically could refer to any similarly shaped span of trenchant iron used for the purpose. Even various improvised clubs used as weapons by Gamelyn are not described as lengths of wood, but as a pestel in one instance $(122,128,138,140,152)^{13}$ - essentially an enormous, bat-shaped kitchen pestle used for grinding grain - and as a cartstaf ('the axle of a cart' [586]) in another. This recalls Havelok's improvised cudgel, variously described as a 'door beam' (barre [1794]), ${ }^{14}$ then as a 'door tree' (dore tre [1806]), and finally as just a 'tree' (tre [1821]), but never as a comparative length of wood of similar weight and dimension. Indeed, Havelok goes further than Gamelyn in metaphorically describing assorted rods, poles, or batons of any length used for any purpose - from staves in battle to boundary markers in games - as a tre to emphasis their form and substance with reference to a recognized Platonic Form rather than listing that form's attributes. Ong notes that such description is typical of 'an oral culture [which] simply does not deal in such items as geometrical figures, abstract categorization, formally logical reasoning processes, definitions, or even comprehensive descriptions... all of which derive not simply from thought itself but from text-formed thought' (54-55).

10. All references and quotations from Havelok refer to lines in the edition of Herzman, Drake and Salisbury (11-72), hereafter cited as HDS.

11. All quotations from Havelok refer to lines in the edition of HDS (73-176). A second reference to the king's mark as a kunrik occurs in line 2143.

12. All quotations from Athelston refer to lines in the edition of HDS (341-84).

13. All quotations from The Tale of Gamelyn refer to lines in the edition of Knight and Ohlgren (184-226).

14. The context makes the referent clear: Avelok it saw, and thider drof / And the barre sone ut drow, / That was unride and gret ynow, / And caste the dore open wide ('Havelok saw it, and ran thither, and promptly withdrew the beam, that was unwieldly and large enough, and cast the door wide open' [1793-6]). 
In a similar vein, there is a causal relationship between objects and their practical utility, with their intended uses being accomplished merely by possessing or brandishing them rather than actually employing them as tools. Neither Gamelyn nor Havelok ever swing their improvised weapons; just by wielding them, their foes are defeated. Likewise, Athelston's culprits either pass their ordeal or they fail; the ploughshares never burn, cut or scorch them. Although there is a detailed description of the fisherman Grim's nautical equipment in Havelok, there is never any mention of how (or if) he uses them; sails are only handled for fabricating makeshift clothes (855), and riggings are only used for binding prisoners (2507). When Grim rows out to sea, however, as soon as his ship is a mile out (722), he relinquishes responsibility for his voyage to the wind, which takes him safely to England. This aspect of inanimate objects taking responsibility for themselves is even more pronounced in Horn, where ships move mysteriously as if by magic; they ride (139-40), bring (1104), lurch (1425), make their way (1305), and arrive (135-36) - or not - as if on their own accord. They are never anchored, but 'stand' (600-1, 1031-32, 1451), apparently of their own volition, as if waiting patiently for an old friend. Horn even thanks a boat for not drowning him, wishes it safe travels, and gives it messages for his family and foes back home (141-56). Such objectaction alignment corresponds to oral cultures' avoidance of detailing techniques in any manner that might read as a modern manual, or of explaining complex skills that would normally be performed intuitively by those who had mastered them through hands-on apprenticeship rather than book learning.

Thus, while all four of these romances are seen to be much more situational than any modern narrative - invariably describing new objects through analogies with known objects that they resemble rather than by abstract concepts such as volume, dimension or mass - as these brief examples show, this characteristic appears to be more pronounced and more frequent in the earlier tales than the later ones.

\section{I (b): Content is Presented as Close to Human Lifeworld}

A second way in which the early romances in particular reflect orally-based thought is in methodically remaining 'close to the human lifeworld' (Ong 42). That is to say, they use 'few statistics or facts divorced from human or quasi-human activity' (43), which are 'analytic categories that depend on writing to structure knowledge at a distance from lived experience' (42). Generally speaking, these English verse romances remain intensely concerned with 
what is happening to individual characters in their own immediate time and place, all of which is inextricably defined by on-going events occurring in proximate surroundings. There is little internal reflection on chains of consequence, or concern over what might be happening simultaneously elsewhere.

The dilemma of Horn's beloved Rymenhild, for example, only develops after he has been gone seven years, when she begins dictating letters for him in her own present (929-44); Horn receives one of her messages in his own separate present, unchanged from the moment when the narrative shifted to Rymenhild's dictation (945-74); as the messenger returns to Rymenhild, he dies in a third individual personal present of his own (975-90). Since his death occurs under Rymenhild's window, it effectively returns the narrative to her, but despite the messenger's time away, her situation has evidently remained static and entirely unchanged since the moment he initially left her. That this is as it should be is demonstrated by Horn's reaction upon receiving the message, for although it motivates him to return to Rymenhild and save her from a forced marriage, he shows no concern that the situation might or even could have changed in the days or weeks it took the messenger to seek him 'in every land' (942). He also seems unworried that further events could unfold before he returns; rather than setting out immediately, he sends the messenger ahead of him to announce his imminent arrival 'on Sunday at noon' (974), and aptly enough, when he finally does come into her presence more than a hundred lines later, he discovers the situation still poised at the precarious point that existed when Rymenhild first began dictating her letters (1115).

In Havelok as well, nothing seems to change in Denmark when following events in England, and nothing really changes in England when characters are active in Denmark, though years or even decades elapse between shifts from one location to the other. ${ }^{15}$ Likewise in Athelston, the pressing situation in London hardly changes whenever the narrative follows messengers to Dover or Canterbury, though here at least, the possibility that events could develop causes the archbishop to use up nine palfreys in his haste to reach London (381), pushing the 'good horse' of the messenger accompanying him so hard

15. For example, Havelok is spirited away to England where he grows up as the son of a fisherman, then is employed in the kitchen of Earl Godrich, who forces him to marry his ward, Princess Goldborough, in order to deprive her of the throne. The couple flee to Denmark, where the usurping Earl Godard is apparently as unchanged as the political situation he controls. Havelok then overcomes Godard after various exploits, becomes king and then returns to England with an army to overthrow Godrich, where no significant changes seem to have taken place in Havelok's absence. 
that it falls down dead on London Bridge when they arrive (385). The late Gamelyn is even more of an exception in that the eponymous hero's brother locks him out of the house when he goes wrestling (289-90), becomes sheriff when he flees to the forest (691-93), and names him an outlaw in his absence (697-702). This causes a messenger to be sent speedily to Gamelyn's faithful brother Sir Ote, who stands surety for the youth (740), but when Gamelyn is subsequently late returning to court, Ote is nearly hanged in Gamelyn's stead after their nefarious brother bribes judge and jury behind their backs (783-86).

While all of these narratives remain closer to the human lifeworld than anything found in well-crafted modern narratives, this characteristic is seen to diminish as time progresses. Horn and Havelok, for example, cannot even imagine events occurring without them, and while characters in Athelston can, they ultimately never do. Gamelyn, however, seems to be fully empathetic, with characters not only realising that events might occur in their absence, but where they actually do occur. This progression, in which the self-referential introspection of the earlier tales diminishes as time goes by, seems to suggest that later romancers and audience alike increasingly rejected as untenable the solipsistic outlook characteristic of orally-based thought that had been accepted as realistic in the earlier tales.

\section{I (c): Homeostatic Relevance and Continuity}

Just as a mind structured by orality favours a solipsistic view of reality, orallybased societies strive to maintain cultural homeostasis synchronically by 'sloughing off memories which no longer have present relevance' (Ong 46), either rejecting them or making them conform to contemporary actualities. Evidence of this sort of reanalysis of information, in which 'the integrity of the past was subordinate to the integrity of the present' (48), is more palpable in the earlier romances than the later ones.

\section{I (c) 1: Horn's Viking Saracens}

The most obvious example of homeostatic levelling is Horn's famous Sarazins kene ('bold Saracens' [40]), who set the plot in motion by invading the young hero's homeland of Suddene with fifteen ships. Horn's father, King Murry, accompanied by only two retainers while pleasure riding on the beach, encounters the invaders and straightaway asks their intent. He is told by one of their number, a payn ('a pagan' [45]), that they are there 'to slay the people of your 
land, and all that love in Christ' (47-48). When Murry and his two knights dismount to fight in the pre-Conquest Germanic fashion, they are immediately killed by the shiploads of attackers, who subsequently occupy the kingdom before banishing Horn.

Much ink has been spilt debating the true identity of this first reference to Saracens in Middle English romance, but the general consensus is that they represent a conflation of the most immediate perceived threat to thirteenthcentury Christendom, the advanced Muslim civilisations of the Near East, North Africa and Islamic Iberia - who never invaded or even raided England ${ }^{16}$ - and much earlier 'heathen dogs' (602) from Scandinavia, who did so more or less annually from 873 to 1066 (Battles 2013, 18-23; Hawes 16-17; Harrill [web]; Speed 564-95). Folk memory of such Viking raids seems alive and well in Horn's description of the Saracens:

The pains come to londe

And neme bit in here bonde

That folc bi gunne quelle,

And churchen for to felle. (63-66)
The pagans came to land, and took it in their hand; they began killing the people, and to raze churches.

Like Horn's Saracens, historic Vikings actually did 'come into the land', not only raiding it, but 'taking it into their hand', and establishing their own independent sovereignties in the north and east of England, such as the Danish kingdom of forvik at York. They had a tradition of killing the people; Murry's fictional encounter is highly evocative of the first recorded fatality of a Viking raid in 787 , in which a sheriff was slaughtered by Norsemen on a beach in Dorset because they resented his 'authoritative tone' when he rode there to confront them 'with a few men' (Giles 14-15). Indeed, Old English reference to encounters such as these are so frequent that it could be considered a cultural touchstone of the Anglo-Saxon worldview. Old English chronicles frequently record Vikings slaughtering English defenders on beaches, including the historical Battle of Brunanburh (CE 937) and the Battle of Maldon (CE 991), both immortalized in verse.

The historically attested Viking tradition of carrying out annual attacks on the English then began in earnest a few years later when, according to Manuscript D of the Anglo-Saxon Chronicle: earmlice boepenra manna hergunc

16. The infrequent raids by Barbary pirates on the south coast of England never really began until the seventeenth century. 
adilegode Godes cyrican in Lindisfarnaee purb breaflac 7 manslibt ('the raiding of heathen men miserably devastated God's church on the island of Lindisfarne through looting and slaughter' [Ten Harkel 177]). The lucrative success of such raids against rich island monasteries protected only by unarmed, peaceable monks no doubt encouraged these opportunistic 'heathens' to target them. It is easy to understand how such regular pillaging might come to be seen by its English victims as a direct attack on both their Christian religion and its practitioners. Thus, while it is true the historically attested heathen Vikings 'are never said to have intended to stamp out Christianity or impose their own religion' (Speed 585) - an argument sometimes used to question the validity of their association with Horn's invaders - that doesn't make them any less likely a prototype for Horn's Saracens than any force of Islam, which never carried out any such attack in England at all. It seems that the most logical explanation is that, in order to make indistinct memories of ancient atrocities relevant, the original Viking perpetrators - no longer a viable threat anywhere in Europe after 1066, but especially not in those parts of England that came to embrace them as ancestors - were replaced in popular memory by the most widely feared 'other' of the day, Saracens.

\section{I (c) 2: Havelok's Danes Battling the English in Norman Fashion}

An excellent illustration of the way in which ancient Viking enemies could become integrated into their erstwhile victims' heritage is provided by Havelok, a tale whose origins have been localized to the East Midlands heartland of the old Danelaw (Shannon 458; Scattergood 178; Kaeuper 52; Carpenter 209), and one whose title character perfectly epitomizes how a Danish conqueror could become a beloved English liberator. Havelok is born to rule Denmark, but like Canute the Great, righteous victory and a fortuitous marriage allow him to become a popular king of England as well. ${ }^{17} \mathrm{He}$ is a purely Scandina-

17. The Danish prince Cnut (Canute) Sweynsson (c. 990-1035) became 'king of all England' in 1016 through conquest and treaty after the death of Athelred the Unready, 'king of the English', whose wife, Emma of Normandy (c. 984-1052), he married the following year. He inherited the crown of Denmark in 1018, and was recognized as king 'of the Norwegians, and some of the Swedes' by 1028, thereby establishing in personal union (like his father) a powerful empire centred on the North Sea. He seems to have been particularly fond of England, which apparently grew fond of him in return, and has even been remembered as 'the most effective king in Anglo-Saxon history' (Cantor 166). He died peacefully in Shaftsbury in 1035 , and was interred in Winchester Cathedral, where his bones still reside. 
vian warrior with inauspicious beginnings, but like the celebrated Beowulf, his inherent nobility allows him to become a admired hero of English legend.

Some traces of a difference between English and Danish identity can still be vaguely discerned, especially in Godrich summoning an English ferd ('army' [2548]) - using a word that specifically designated a defensive national levy (fyrd) in Old English - to defend against Havelok's invading uten laddes here ('army of foreign troops' [2580]), using a word that specifically referred to an invading force of foreigners, specifically Danes (MED). Godrich also falsely accuses Havelok's Denshe men ('Danish men' [2575]) of committing the same sorts of atrocities once associated with Vikings: burning churches, binding priests, killing monks and nuns, and enslaving native survivors (2575791). But in Middle English here and ferd were homeostatically undifferentiated, essentially having become synonyms for 'army' (MED). The narrative invariably casts Havelok's troops in a favourable light, with the bardic narrative voice objectively referring to his forces as a ferd, even in Denmark, suggesting that, if the words still carried different connotations, it had become one of 'us' versus 'them' rather than 'English' versus 'Dane'. Indeed, when the two sides join in battle, they are both antagonistically ferdes (2683); but when they unite peacefully to celebrate Havelok's coronation, they become a here (2942). In this it seems that the difference between 'English and Danish, high and low' (2945) had been effectively neutralized, and perhaps by that point the difference between Danish and English stock in the popular mind was no greater than the difference Englishmen of later centuries came to feel between Norman and Saxon.

At the time Havelok was written, however, the latter distinction must have still been very much alive (see Aertsen; Pearsall 11). Dominique Battles (2012) even demonstrates that the tale was probably intended to remind the audience of Anglo-Danish unity in the face of Norman oppression in the years immediately following the Conquest. Be that as it may, the distinctions were clearly already starting to blend. In order to keep the homeostatic present intact, even historical verisimilitude was sacrificed in order to make the legend not only relevant to the present, but - ironically to a modern mind with written witnesses - arguably to make it more realistic and credible. This aspect is readily seen in battle scenes, which sometimes accord reasonably well with Germanic pre-Conquest practices appropriate to the setting, but are more often anachronistically reflective of chivalric Norman practices that would be expected at the time of writing. The abovementioned manner in which 
Godrich summons his ferd, for example, corresponds to Anglo-Saxon practices, as does the way in which they cautiously proceed to confront the enemy:

And lopen on stedes sone anon;

And toward Grimesbi, ful god won,

He foren softe bi the sti. (2616-18) and [they] promptly leapt at once on steeds, and [galloped] vigorously towards Grimsby; they rode the road quietly

When the armies meet, however, rather than dismount to fight, as Horn's father had done when confronting the 'Saracens', both sides engage anachronistically from horseback in the Norman fashion. Havelok's sword-wielding foster brother, Hugh,

...smot ful sore

An erl that be saw priken thore

Ful noblelike upon a stede. (2648-50) very injuriously struck

an earl that he saw riding there

full nobly upon a steed

The noble Ubbe likewise 'immediately let his steed gallop to Godrich with a good spear' (2651-52), attacking the enemy from horseback with a lance - a practice that only became customary in England after the late-twelfth-century introduction of chivalry (see Cartwright, and Ford [forthcoming]). Only once they had both been unhorsed did they draw their swords (2658-59), reserving swordplay for the close-range fighting that took place on foot only after both knights' horses had been eliminated (HDS 59). Finally, Havelok himself 'came charging upon a steed' (2702), offering to forgive Godrich in yet another anachronistically chivalrous flourish if he will surrender (2715-21; see Strickland 138).

When Godrich refuses, he is tried according to the rules of French jurisprudence rather than English law, as French and Hale observe:

The jury is of no fixed size. It is made up of peers of the accused. No one acts as prosecutor, although the complainant may state his case... and the defendant is not questioned. The king can take no part in the actual trial, and must abide by the verdict. (158)

Godrich is then led to his execution ignominiously tied to a mare's tail (281932), a typically English humiliation that contrasts with being flayed alive in the continental fashion (Rouse 104-5; Bellamy 13; Barron 1981, 187-202), which was the fate suffered by his Danish counterpart, Godard, before Havelok's departure for England (2493-503). Even the final procession to London for Havelok's coronation is anachronistic. London only gradually became the capital 
of England after William the Conqueror was crowned there in 1066, before which the traditional capital was Winchester, which is at least recognized as Athelwold's seat at the beginning of the tale (158).

These various examples suggest that - unlike in a completely oral culture, where the need to retain constant homeostasis leads to the rejection of any disparity with its present actuality - a more literate society can make effective use of certain historical facts incongruent with its present reality as long as they do not conflict too much with contemporary understandings of the workings of the world. The author of Havelok, for example, seems to exploit the fact that Winchester was once England's capital (though later seems to forget it), or that Danes once invaded England (but refuses to accept them as ravagers, despite references to pillaging). Nevertheless, such societies might still have difficulty accepting less explicit variances related to the imprecise ways in which the world functions. While it might be possible for the raising of an Old English fyrd to be accurately portrayed - hardly problematic since Middle English ferdes were still raised the same way - a pre-Conquest battle between Danes and Englishmen could only be imagined as following the chivalric Norman rules of engagement that had become conventional throughout postConquest England. Indeed, the cultural updates in Havelok are so extensive that it has even been likened to a 'thirteenth-century handbook for princes' (see Staines), and political analyses of it almost invariably situate it in the reign of Edward I (1272-1307: Battles 2012, 188; Crane 40-52; Delany and Ishkanian; Kabir 31-32, 46-47; see also Stuart). So while Havelok does make some allusions to historical facts or conditions of the period it purports to portray, a great deal of incidental or peripheral information surrounding the story is modernized in a way that subordinates realities of the past to the realism of the present, a transformation highly characteristic of primarily oral culture.

\section{I (c) 3: Athelston}

Like the entirely legendary Havelok, the semi-legendary Athelston also claims to be about a pre-Conquest king, but in this case, rather than being an unattested Danish conqueror from an imprecise moment in the distant past, the fictitious Athelston is ostensibly the historical tenth-century King Athelstan of Wessex (d. 927). There are some allusions to historic details from this first king of all the English, evidently used to lend a semblance of credibility, as would be done in a fully literate culture, but here they are imprecise and misremembered (see Hibbard Loomis 1921). Like the historic Athelstan, the fic- 
tional Athelston is childless, but unlike his namesake who never married, this is evidently because he recklessly kills his unborn child. Both are succeeded by an Edmund, but the half-brother who followed the true Athelstan becomes Athelston's nephew in the romance, where he furthermore seems to be confused with the ninth-century king of the East Angles, St Edmund the Martyr (fl. 646-62). Most efforts to infuse the narrative with factual details from history end there. Like Havelok, this Anglo-Saxon king's capital is also at London, and any political reading of the tale also places it more in the time it was written than the time it was set, though in this case that is the fourteenthcentury world that is also inadvertently portrayed in Gamelyn rather than the late thirteenth century of Havelok.

Indeed, even the 'concrete realism' often admired in the tale's description of London and the Old Kent Road is only anachronistically accurate. The tale mentions 'the palace and church of Westminster, Charing Cross, [Fleet] Street, and the Elms, the old place of execution at Smithfield', as well as the route 'from London bridge to the castle of Stane... and on to Dover' (Hibbard Loomis 1921: 225). That this is the Plantagenet capital rather than the Mercian trading centre, however, is not difficult to discern from mention of Charynge-cross ('Charing Cross' [335]), named in reference to the Eleanor Cross erected there by Edward I in memory of his wife after her death in 1290. And while instances of trial by ordeal involving a walk over red-hot ploughshares are apocryphally ascribed to pre-Conquest England - most notably in the case of Queen Emma, ${ }^{18}$ the Norman wife of both King Athelred the Unready and Canute the Great - it has also been demonstrated that despite any allusions to Anglo-Saxon precedents, the tale is more concerned with current legal practice (see Young). Indeed, allusions have been found in the tale 'to

18. As mentioned in footnote 17, above, Emma of Normandy was the wife of King Athelred, whose eldest son from his first marriage, Edmund Ironside, became king when his father died in 1016. This Edmund soon lost the northern and eastern parts of England to the Danish prince Canute, who was welcomed in those regions, known as the Danelaw, which was largely inhabited by descendants of Danish Viking settlers from previous centuries of invasion. When Edmund died several weeks later, the Anglo-Saxons in the rest of England accepted Canute as king in accordance with their treaty under Edmund. Canute then married Emma, whose sons from her marriage to Athelred were sent to the court of Emma's brother, the Duke of Normandy, where they grew up in exile. These sons seemed to have had little affection for their mother, who became regent for their younger half-brother as king of England when Canute died, and the youngest was tortured and killed when invited to England to visit her. A thirteenth-century legend claims that when Emma was accused of infidelity after the eldest son, Edward the Confessor, finally did become king, she proved her innocence by walking over red-hot ploughshares. 
events ranging in date from the tenth to the late fourteenth centuries, including the struggle between Henry II and Thomas Becket and the challenge of the barons to Richard II' (HDS 341). Some go so far as to conclude that 'for Athelston the King we may substitute the tyrannical Richard II, who dispensed with due process for his rivals, whom he then unlawfully imprisoned, exiled, or executed' (HDS 344, Rowe 88). While such late dating is probably exaggerated, the mere fact that these ideas can be entertained demonstrates the extent to which the romance subordinates the past to the present.

Athelston also modernizes the past in its 'outlook toward law, justice, authority and property' which like Gamelyn, shows concern with 'the growing social crisis of the latter fourteenth century' (Bradbury 1998, 25). Both were written at a time when 'the structures of family and feudal hierarchy, [and] the institutions of justice... no longer seem to promise security and success' (Crane 74). This situation could be partially attributed to the massive legal reforms begun by Edward I (especially shortly after the time Havelok was written), and the consequent arbitrary reliance on written statutes that did not keep pace with societal change in subsequent generations, as oral customary law had tended to do. Indeed, in contrast with Horn and Havelok - where the heroes' strict adherence to traditional Germanic law invariably results in quasidivine justice - Athelston's arbitrary judgments and abuse of royal authority instead result in the killing of innocents with impunity when a kick to his pregnant wife's belly causes her to lose their unborn son. It is not difficult to interpret this literal miscarriage as a metaphor for miscarriages of justice being carried out in the king's name in law courts as early as the reign of Edward III (1327-1377) - when 'confidence in law breaks down' (Crane 54).

Overall, it is easy to see that Athelston is not so much a factual anecdote from the past extolling old ways as a lesson for the present, but largely a homeostatic critique of the present that makes use of a fancified version of the past to lend it clout. No matter how clumsily it is done, however, Athelston's attempt to portray that past accurately by incorporating divergent historical realities rather than erasing them is evidence of a shift towards a more literately inclined way of thinking.

\section{I (c) 4: Gamelyn}

Gamelyn is purportedly set in the reign of Edward I, but is frequently considered to more accurately reflect conditions that existed at the time it was written, late in the reign of Edward III. It has thus been linked with Athelston in 
'presenting the achievement of justice as elusive and problematic', and in addressing 'the social and political unease of the later fourteenth century, as virtually every medieval institution faced powerful challenges from all sides' (Crane 74). More specifically, it has frequently been recognized that many details of the story which might strike a modern audience as far-fetched - such as a split inheritance at the beginning of the tale, Gamelyn's nefarious brother rapidly becoming sheriff, the help Gamelyn gets by essentially bribing a servant, the existence of outlaw bands, the corruption of the courts, and even the violence perpetrated against it - are fairly accurate depictions of rural gentry life under England's mid- to late-fourteenth-century 'bastard feudalism' (Bradbury 2012, 139-40; Eckert 134; Field 26; Kaeuper 53; Lucas 47; Ludwikowska 68; Menuge 48; Sartore 159; Scattergood 165-66; Shannon 456-58; Shippey 84).

As valid as these points may be, it should be remembered that Gamelyn is the only one of these four romances to have a post-Conquest setting, and also the only one claiming to recount events that took place only a few generations before. Clearly, any such romance would not find favour if it were not accepted as believable by its audience, some of whose members could conceivably have been alive when the narrative was set. And despite claims that it must have had 'a strange popularity' (Scattergood 160), or that it was not popular at all (Knight and Ohlgren 184), the fact that there are more manuscript copies of Gamelyn than any other Middle English verse romance demonstrates that it must have enjoyed at least a modicum of favour. Even if that popularity was derived from a false attribution to Chaucer, as is generally presumed, it still would not have enjoyed any popularity at all if its audience, who would be well-placed to know, had rejected the romance as spurious. That it nevertheless enjoyed a respectable degree of acceptance suggests that its description of the late thirteenth century must have been accurate enough to be considered credible by an audience able to judge its plausibility from personal or familial experience. It therefore seems that, though there may have been a certain degree of homeostatic updating, it did not rise to the level of distorting the past so much that it was rejected by individuals who might have lived it.

Overall, some of the most interesting examples of the ways in which these romances rely on orally-based thinking more than modern discourse is in the extent to which they employ homeostasis in revising historical fact to make it conform to present conditions. Horn does so shamelessly, changing 
historical facts irrelevant to the present (Viking enemies once attacked) so that they fit with possible present realities (Muslim Saracens might). Havelok does so with a bit more reticence, accurately recalling some ancient history (Danes once invaded England), but is unable to accurately portray conditions that would have been different (they must have fought and acted like chivalrous Normans because that is the way it is done). Athelston tries to incorporate concrete facts it knows of the past (King Athelstan of Wessex was succeeded by a second-degree relative named Edmund), but cannot help confusing details and makes obvious blunders (his half-brother becomes his nephew, who is impossibly the ninth-century East Anglian king, St Edmund). Finally, Gamelyn tries very hard to portray a recent past, and apparently does so well enough to find general acceptance by an audience some of whose members might have first-hand knowledge of the time, but, like Havelok and Athelston, while it correctly reports some incontrovertible concrete generalities (only sheriffs declared outlaws; itinerant justices ruled on criminal cases of delivery), it anachronistically gives them present colouring (violence against courts was more characteristic of late fourteenthcentury bastard feudalism). Such examples demonstrate that not only do all of these romances display the homeostasis Ong identifies as characteristic of orally-based thought, but interestingly, the latter romances seem to have more scruples over doing so.

\section{I (d): The Romance Fund Allows Narratives to Remain Traditionalist and Conservative despite Homeostatic Change}

In order to maintain a semblance of authenticity, it seems that the above inclinations towards homeostasis are balanced by a tendency for narratives to sustain 'a highly traditionalist or conservative set of mind that... inhibits intellectual experimentation' (Ong 41). Such reluctance to consciously embrace novelty results in a general conservativity in the telling of the tales, which helps to obscure innovations by couching them in a comfortingly familiar storyline and structure. This accounts for the existence of the so-called romance fund, the aggregate of commonplace themes, topoi, and stock characters that are repeatedly found in medieval romance. ${ }^{19}$

19. I am indebted to Professor Jeremy J. Smith of the University of Glasgow, who first provided me with the notion of the romance fund many years ago. 
The typical framework of a romance is that of exile and return, often doubled, in which a hero sets out on a specific quest, itself interrupted by an unexpected adventure, which the hero must resolve before completing his mission and successfully returning to his starting point. The impetus for either the quest or adventure is usually to earn the love of a higher status maiden, often daughter of the hero's king or lord, or the status needed to be worthy of her. Stock characters and symbolic exchanges help the plot along: loyal ladies provide magic tokens, such as rings, to protect the hero; itinerant minstrels, messengers or holy men change the hero's identity by changing clothes with him; switching modes of transport (walking instead of riding, or even riding different kinds of mounts) can be a de facto change of status; while the formal exchange of words in trothplights with loyal companions (particularly sworn brothers), lady loves (sometimes calumniated queens), and traitorous friends (especially perfidious stewards) both motivate and hamper the hero's actions.

Although no romance bears all these hallmarks, Horn and Havelok are much better archetypes than Athelston, which itself is a better example than Gamelyn. Horn and Havelok are both royal characters who become fair unknowns when they are exiled from home as youths; both are forced to flee from a point of refuge due to a love interest; each overcomes hardships, making him worthy of that love interest; both destroy their enemies, return home, marry their love, and become king. Horn is slightly more prototypical in having both loyal companions and traitorous friends, and in going from point A to B, B to $\mathrm{C}$, and back, while Havelok's enemies are largely external, though they are traitorous stewards, and he really only goes back and forth between A and B. But both heroes are more traditional than Athelston, a messenger in his youth who is never exiled before marrying and becoming king at home. He becomes his own worst enemy after being deceived by a false friend, but redeems himself through the unwelcome intervention of his long-suffering wife and a loyal companion. All three of these pre-Conquest kings, however, are infinitely more heroic than Gamelyn, who is not even a knight. His enemy is his brother, a manservant takes the place of a loyal lady, and his exile is only as far as the forest. He becomes an outlaw, and is redeemed by defying the law rather than following it, attacking the court and executing its officers.

It is easy to see that Horn is the most traditionalist and conservative of these romances, while Havelok deviates from the prototype only slightly; Athelston seems a bit more experimental, but Gamelyn is undoubtedly the most innovative of all. This progression from highly conservative and traditional to 
innovative and experimental perfectly reflects the sort of evolution oral cultures go through as they become more literate, exchanging a resistance to unsettling novelty for a thirst to embrace the new and exciting.

\section{I (e): Agonistically Toned}

The abovementioned traditionalist conservatism naturally results in the romances being 'agonistically toned' (Ong 43). This typically means that wholly good protagonists enjoy 'the fulsome praise [of] the old, residually oral, rhetoric tradition [which] strikes persons from a high-literacy culture as insincere, flatulent, and comically pretentious' (45). This corresponds almost exactly to Donald Sands' observations that 'romance characters tend to be flat non-pareils: they are paragons of beauty, goodness, saintliness', and that 'usually no humanizing and magnanimous inner weakness arises to give their perfection credibility and strength' (7). He further notes that these flat characters 'lack inner contradictions, ethical standards based on element other than convention and lip service, [and] true inner turmoil (despite their excessive displays of grief or devotion)' (7). Such heroes and heroines are invariably pitted against wholly bad antagonists, who suffer the 'name-calling or vituperation' characteristic of 'oral or residually oral cultures' (Ong 45). Such praise and vilification are characteristic of 'the highly polarized, agonistic, oral world of good and evil, virtue and vice, villains and heroes' (45).

Horn, for example, is all good:

He badde a sone that het Horn;

Fairer ne mighte non beo born,

[...] Fairer nis non thane be was:

He was bright so the glas;

He was whit so the flur;

Rose red was bis colur.

He was fayr and eke bold,

And of fiftene winter bold.

In none kinge riche

Nas non bis iliche. (9-20)

Ne beo we noght iliche:

Horn is fairer and riche,

Fairer bi one ribbe

Thane eni man that libbe. (318-20)
[King Murry] had a son that was called Horn;

fairer might none ever be born,

[...] None is fairer than he was:

he was bright as glass;

he was white as the flower;

rose red was his colour.

He was fair and also brave, and fifteen years old.

In no kingdom

was his equal.

We are not alike;

Horn is more handsome and rich,

fairer by one rib

than any man who lives. 
He battles with all-bad Saracens, who are consistently 'fully evil pagans' (1330) and 'heathen dogs' (602). ${ }^{20}$

Havelok is likewise all good:

Havelok was a ful god gome-

He was ful god in everi trome;

He was the wicteste man at nede

That thurte riden on ani stede. (7-10)

Ful sone it was ful loude kid

Of Havelok...

[...]

Hw he was fayr, bw be was long,

Hw be was with, bw he was strong;

Thoruth England yede the speche,

Hw he was strong and ek meke;

In the castel, up in the balle,

The knithes speken therof alle. (1061-69)
Havelok was a very decent fellow;

he was very good in every respect;

he was the most valiant man in [time of] need that might ride on any steed.

Very soon it was made well known of Havelok...

$[\ldots]$

how he was fair, how he was tall, how he was valiant, how he was strong; the word went throughout England how he was strong, and also modest/kind; Up in the hall in the castle, all the knights speak thereof.

He battles with the 'wicked traitor' (665) Earl Godard, and the equally treacherous Earl Godrich 'that foul traitor, that shat-upon churl' (2533) - both of whom are consistently qualified as 'wicked' and 'foul' numerous times, and are both denigrated individually as either fudas (319, 405, 482, 1134, 1101 ) or Sathanas ('Satan' [1135, 2512]). While the incredulous literate mind rejects both the irredeemably evil antagonists as well as the entirely flawless heroes, both are typical of 'oral memory [which] works effectively with "heavy" characters, persons whose deeds are monumental, memorable and commonly public' (Ong 69). It is therefore not entirely surprising to find them in early transitional text, such as these first two English romances.

In this, the impeccable Havelok and Horn contrast noticeably with the later Atheston - whose goodness is somewhat flawed by misjudgements and misdeeds - or the simple squire, Gamelyn, whose deeds are more personal than monumental, and private rather than public. Athelston errs in rashly accepting the unsubstantiated accusations of one sworn brother against another, causing anguish to those closest to him: his brother-in-law, the earl of

20. The Saracens are denigrated as pagans a total of nine times $(45,63,80,82,85,151,812,885$ and 1330), and simply as 'dogs' (with the sense of 'heathens') four additional times $(605,837$, $889,1381)$. 
Stane; the earl's wife, Athelston's sister; the children of the earl and countess, Athelston's nephews. This in turn causes discord between himself and his loyal friend, the archbishop of Canterbury, and strife with his faithful wife, who loses their unborn child due to his angry violence.

These two tales nevertheless have characters whose flatness tests the credibility of a modern literate mind. Though hardly heroes, the queen, Stane and the archbishop nevertheless remain wholly good, and it is through their intervention and guidance that the king makes amends, eventually meting out cruel justice to the nefarious earl, who is invariably wholly bad. For his part, the contemporaneous Gamelyn is morally good, but is flawed in his rashness, and is furthermore portrayed as politically weak and ineffectual before his physical strength and the aid of dignified allies helps him to overcome his brother, John, who is consistently all bad. In these respects, Atheston and Gamelyn themselves foreshadow the 'colorless personalities, who cannot survive oral mnemonics' (Ong 69), but more peripheral characters are still relatively one-dimensional; the old oral poetic structure has not yet been altered to the point where narratives can completely abandon heavy figures, and 'move comfortably in the ordinary human lifeworld typical of the novel' (68), where the hero gives way to the antihero (70).

Despite the dynamism of their protagonists, however, Gamelyn and Athelston are just as agonistically toned as Horn or Havelok in their 'enthusiastic description of physical violence' (Ong 44). The description of Athelston kicking his pregnant wife in the stomach is graphic (283-84), while the gruesome trial by ordeal in which his victims are forced to march over flaming redhot ploughshares is described in vivid detail (241-51). Gamelyn furiously drives off henchmen with a club (117-30), breaks a porter's neck by throwing him down a well (301-04), and is himself fettered and mistreated (375-92). He furthermore beats up churchmen so badly that they must be carried away in carts and wains (509-24), breaks his own brother's back and chains him up (515-36), manhandles the circuit court judge (845-47), then slashes the justice's face before having him hanged with the jurors and his brother, the sheriff (874-78). The gratuitous violence in these examples is as explicit as any battle or grisly execution in Horn or Havelok.

Thus, while flaws in both Gamelyn and Athelston show them to be more dynamic characters in a somewhat modern vein, the thirst for gratuitous violence is hardly effaced, though much the same could be said for any number of twenty-first-century Hollywood films. Furthermore, while these romances 
as a whole show that the control of information brought about by writing has not yet entirely effaced the need for agonistic heroes in the old sense, the need to justify their pugnacity by making them paragons of good versus paradigms of evil also declines in the latter romances.

\section{PART I: CONCLUSION}

Out of Ong's nine psychodynamic characteristics of orally-based thought and expression, the five identified as relating primarily to deep-structure frames of thought, examined above, each occur to a greater extent than would be considered acceptable in a modern narrative in all four of these Matter of England romances. Furthermore (while acknowledging that this necessarily limited examination is more indicative than conclusive), all five are found to be more prevalent in the earlier tales, and seem to decline relative to the passage of time. Since one logically anticipates the younger romances to increasingly reflect less dependence on orally base thought as English society became increasingly more literate, this is exactly what one would expect.

\section{Part II.1: Disparity between DeEP-Structure Conceptualization and Surface-Structure Verbal Patterning}

Curiously, however, the inverse seems to be true for Ong's four remaining characteristics, here identified as relating primarily to surface-structure expression. If these surface-structure expressions are merely outward projections of deep-structure thoughts - which accounts for them emerging as easily remembered templates of repetitive verbal patterning, conducive both to the organization and retention of such thoughts - one would expect their frequency to decline as evidence of orally-based thought itself diminished. Instead, these expressions actually seem to become more frequent and more complex in the repetitive expressions so often identified and analysed as either true oral-formulaic formulae, or at the very least residually formulaic expressions of the oral tradition. It is in this respect that the retention of such formulae can be considered skeuomorphic. Although even some of Lord's SerboCroatian 'singers of tales' were always more given to 'ornamentation' than others (24), for them the decorative quality of the formula was secondary to its mnemonic utility in using 'these formulas to facilitate composition' (22). Indeed, unlike the Middle English romancers' formulae, whose florid repeti- 
tion and length becomes increasingly more redundant as time goes by, for Lord's illiterate bards, 'these devises have to be used sparingly, because the audience will not tolerate too many of them' (22). As the objects of such frequent analysis elsewhere, the structure and identification of these formulae can be treated briefly here, but some examination is nevertheless required to demonstrate the extent to which they are increasingly used gratuitously as decoration rather than essential structuring elements.

\section{II.1 (f): Narratives are Aggregative Rather than Analytic}

The abovementioned traditional conservatism and agonism in orally base thought naturally lead narratives to be aggregative rather than analytic, 'carry[ing] a load of epithets and other formulary baggage which high literacy rejects as cumbersome and tiresomely redundant' (Ong 38). This is significant because it accounts for the retention of long-established epithetic constructions of the sort that are particularly characteristic of oral compositions. As Ong notes, 'oral folk prefer, especially in formal discourse, not the soldier, but the brave soldier; not the princess, but the beautiful princess; not the oak, but the sturdy oak' (38). All four of these romances are replete with such sobriquets, including neologisms made for the nonce, such as Horn's 'Rymenhild the bright' (386, 394, 1443), or Havelok's 'Lincoln, the good borough' $(774,848)$, though the latter's 'dear son' $(840,2170)$ is as banal as Athelston's 'noble cleric' $(56,100,112)$, or Gamelyn's nefarious brother, invariably called 'the false knight' a total of thirteen times, ${ }^{21}$ three times more often than Havelok's earls are denigrated as 'foul' or 'wicked traitors'.22

Though noticeable, this usage is still perhaps the least noteworthy due to its common occurrence in modern English as well, where such 'formulaic sequences are ubiquitous' (Schmitt and Carter 2). Colloquial speech makes frequent use of such 'multi-word items' (Moon 44, Schmitt and Carter 2) - such as my boy, good girl or even the Big Apple - and even written discourse is greatly affected, with 'formulaic sequences of various types' accounting for over $50 \%$ of some modern texts analysed, notably fairy tales (Schmitt and Carter

21. Lines: $192,349,361,379,459,467,611,694,719,735,780,796$ and 879.

22. Viz: 423: 'moste swike'; 627: 'fule swike'; 1109: 'ful swikel'; 1159: 'That wicke thrall that foule swike'; 2401: 'wicke swike!'; 2451: 'ful swike'; 2463: 'fule swike!'; 666: 'wicke traitour'; 693: 'Fro that traytour, that wicke man'. 
1, Erman and Warren 2000). As the examples show, however, particularly $H a$ velok and Gamelyn, there nevertheless seems to be a marked increase in such usage after Horn, suggesting the increased usage to be more stylistically skeuomorphic than functionally structuring.

\section{II.1 (g): Expressions are Redundant and Copious}

These romances also share Ong's third characteristic of orality in being 'redundant or "copious" (39), repeating and reiterating information so much that it seems 'often bloated with "amplification", annoyingly redundant by modern standards' (41). This too results in collocations whose verbal patterning and repetition meets the requirements of formulaic diction according to the theory of oral traditionalism, though crucially, the degree of variation permitted would often cause the examples to be rejected as true oral formulae by Parry's classical criteria.

Curiously, examples are not as plentiful in Horn as one might expect, and when they do occur, they are often somewhat mixed, as in the example of the hero 'singing merrily' as he 'rides for pleasure':

And Horn murie to singe;

Horn rod in a while

More than a myle. (598-600)

Hi gunne murie singe. (1481)
Horn [began] to sing merrily;

Horn rode for a while, more than a mile.

He began to sing merrily.

Such riding 'at play' or 'at hunting' is a royal activity also pursued by other kings (see Thiébaux):

Murri, the gode King,

Rod on bis pleing... (34-35)

Today, after mi dubbing,

So I rod on my pleing... (633-34)

The king bim rod an buntinge. (650)
Murry, the good king, rode for pleasure...

Today, after my dubbing, as I rode for pleasure...

The king rode at hunting.

While these examples are admittedly brief and limited, that seems to be a result of not being used indiscriminately as formulae sometimes are in later romances. In Horn, formulaic language is used sparingly and concisely to link together bits of information germane to the plot (the character was riding, so whatever occurred happened away from the court), or to anchor specific con- 
notations to those bits of information (Horn is both happy [he sings] and noble [he rides like a king]).

It is much easier to find repetitive occurrence of formulaic expressions in Havelok, where their quantity and quality makes them seem somewhat more gratuitous. A conspicuous example is the frequent reiteration that Havelok (9-10; 25-6; 1970-71), his father-in-law (86-87), or foster-sister's sons (2894$95)$ are the best, bravest, or most stalwart knights in time of need, who could ever ride a horse:

He was the wicteste man at nede

That thurte riden on ani stede. (9-10)

He was the stalwortheste man at need

That may riden on ani stede. (25-26)

He was the beste knith at need

That hevere micthe riden on stede. (86-87)

He is the beste man at nede

That everemar shal ride stede. (1970-71)

That were the beste men at need

That mouthe riden on ani stede. (2894-95)
He was the most valiant man at [time of] need That might ride on any steed.

He was the most stalwart man at need that may ride on ant steed.

He was the best knight at need that ever might ride on any steed.

He is the best man at need that evermore shall ride [a] steed.

Who were the best men at need that might ride on any steed.

As in Horn, it is noteworthy that these repetitive formulae are never repeated verbatim despite being based on the same mental template (see Ford 2002), and would therefore fail Parry's requirements for a formula despite clearly being formulaic. Furthermore, they become conspicuously copious by extending over two lines rather than a single line or hemistich, which might distract from pertinent plot-advancing information around them instead of linking that information cohesively together. ${ }^{23}$ And finally, the positive superlative is anchored to a number of individuals despite being uniquely exclusive, including when the characters so praised are dispossessed and naked (9-10), dying (86-87) or unborn (2894-95).

This distractive, copious quality is even more pronounced in several of Havelok's 'catalogue[s] of expensive food and wine' (Kabir 39) - which like Wolfram's 'long lists of precious stones' derive from the poet's imagination

23. Though Gintsburg (2014) has noted similar development of extempore development in Jbala performance in Morocco. 
and would have been difficult to memorize (Murray, $\$ 4$ ) - and especially its lists of attendees at assemblies, which are particularly rich with amplification:

Hym lovede yung, bim lovede bolde -

Erl and barun, dreng and thayn,

Knict, bondeman, and swain,

Wydues, maydnes, prestes and clerkes. (30-33)

To thee shole comen heye and lowe,

And alle that in Denemark wone -

Em and brother, fader and sone,

Erl and baroun, dreng and thayn,

Knightes and burgeys and sweyn. (1325-29)

Erles, barouns, drenges, theynes,

Klerkes, knithes, burgeys, sweynes,

That he sholden comen anon. (2194-96)

The king dede Ubbe swithe calle

Hise erles and hise barouns alle,

Dreng and thein, burgeis and knith. (2464-66)
Young and old loved him, earls and barons, vassals and retainers, knights, bondsmen and squires, widows, maidens, priests and clerics.

To you should come high and low, and all who live in Denmark; uncle and brother, father and son, earl and baron, vassal and retainer, knights and townsmen and squires...

...Earls, barons, vassals and retainers, Clerics, knights, townsmen, squires, That they should come at once...

The king had Ubbe swiftly call all his earls and his barons, vassal and retainer, townsman and knight.

Such inexact multi-line formulae are also found in Athelston, where, for example, the archbishop's duties in performing 'God's work' are often linked with his office as a 'clerk', whether that diminutive title is accompanied by an attributive adjective or not:

The ferthe brotbir was a clerk,

Mekyl he cowde of Goddys werk. (49-50)

Hou faryth that noble clerk,

That mekyl can on Goddys werk? (100-01)

Ryght weel gretes thee that noble clerk,

That mykyl can of Goddys werk... (112-13)

With bym wente bothe preest and clerk,

That mykyl cowde of Goddys werk. (414-15)
The fourth brother was a cleric,

Much he could [do] of God's work.

How fares that noble cleric,

That knows [how to do] much in God's work?

That noble cleric greets you right well, who knows much of God's work.

With him went both priest and cleric, that knew much of God's work.

Relatively speaking, such expressions appear to be as frequent here as they are in Havelok, but since the nature of Athelston's verse (examined more fully below) tends to block formulae from extending beyond a maximum of two lines, they also tend to be less copious. 
The case is different in Gamelyn, however, whose verse structure allows it to make frequent use of half-line formulae in a variety of situations, and though rather less distracting, they still frequently seem to be used for essentially decorative metrical purposes rather than having any functional utility in linking information together. This ornamental adaptability is seen in the versatility of the formulaic expression, 'evil must/may [one] thrive':

$\begin{array}{ll}\begin{array}{l}\text { 'What now!' seyde Gamelyne } \\ \text { 'evel mot ye the!'. (131) }\end{array} & \begin{array}{l}\text { 'What now!' said Gamelyn, } \\ \text { evil may you thrive }\end{array} \\ \begin{array}{l}\text { Than seide the fals knyght } \\ \text { (evel mote he thee!). (361) }\end{array} & \begin{array}{l}\text { Then said the false knight } \\ \text { (evil may he thrive!) }\end{array} \\ \begin{array}{l}\text { If I faille on my side evel } \\ \text { mot I thee! (444) }\end{array} & \begin{array}{l}\text { If I fail on my side, evil } \\ \text { may I thrive! }\end{array} \\ \begin{array}{l}\text { Than seide a priour, evel mote } \\ \text { be tbreve! (483) }\end{array} & \begin{array}{l}\text { Then said a prior, evil might } \\ \text { he thrive! }\end{array} \\ \begin{array}{l}\text { And if I faile the this day } \\ \text { evel mot I thrive! (582) }\end{array} & \begin{array}{l}\text { And if I fail you this day, } \\ \text { evil might I thrive! }\end{array} \\ \begin{array}{l}\text { But broke bak sherreve } \\ \text { evel mote thou thee! (716) }\end{array} & \begin{array}{l}\text { But broken-backed sheriff, } \\ \text { evil may you thrive! }\end{array} \\ \begin{array}{l}\text { Such another brother } \\ \text { evel mote hym byfalle! (734) }\end{array} & \begin{array}{l}\text { Such another brother, } \\ \text { may evil befall him! }\end{array} \\ \begin{array}{l}\text { The fals knyght bis brother } \\ \text { evel mot he thryve! (780) }\end{array} & \begin{array}{l}\text { The false knight his brother, } \\ \text { evil may he thrive! }\end{array}\end{array}$

Although slightly less copious, this formula is applied as broadly as the example provided from Havelok, occurring in both direct and reported speech, first, second and third person, and while it generally provides negative connotations, it can also be a mild oath as much as a curse. In all this it lacks the particularizing force seen especially in Horn's formulaic expressions.

Taken as a whole, the frequent repetition of such stylized phrases in all the romances is reminiscent of formulaicity, but the variance permitted within each particular occurrence shows them to be formulaic expressions rather than strictly defined oral-formulaic formulae. Thus, despite bearing the redundancy that Ong recognizes as highly characteristic of orality - where it is more natural to thought and speech than is the sparse linearism of analytic thought struc- 
tured by writing (40) - both the quantity and quality of these examples (especially after Horn) suggest that they are being used for some reason other than simply anchoring information in a metrical framework, as would be the case with the Parry-Lord variety of formulae used in cultures of primary orality 'untouched by literacy' (Ong 5). To wit: they are prolix rather than pithy, both defeating the purpose of a formula by distracting from adjacent information rather than anchoring it, and simultaneously becoming more difficult to memorize themselves. Furthermore, they have to be accommodated by the meter, taking up whole series of lines rather than filling them out. They are nevertheless used with growing frequency, suggesting that their distractive nature is increasingly inconsequential, which would be the case if information was being organized literately rather than orally. But even if writing rendered their distractive nature inconsequential, it would likewise render them obsolete and superfluous. Rather than shedding these inoperable vestiges of now redundant constructions, however, even more energy is expended to make them more elaborate, varied and numerous. This development is comparable to the skeuomorphic transformation of the simple, functional abacus and echinus on the unadorned capitals of Classical Greek architecture's Doric order - which sought authenticity by mimicking in stone the features previously common on wooden temples - into decorative Ionic, elaborate Corinthian and finally fussy Composite capitals as functional needs were superseded by primarily aesthetic concerns.

\section{II.1 (h): Syntax is 'Additive rather than Subordinate'}

Since the conservative epithets and redundancies are naturally formulaic in nature, it is hardly surprising that syntactically the romances' language is 'additive rather than subordinate' (36). This means that it relies on paratactical grammatical constructions in which items are listed one after another with or without coordinating conjunctions, rather than hypotaxis with subordinate clauses introduced by subordinating conjunctions, which often 'appears more natural' today (37). Given the paratactic nature of all metrical poetry, especially traditional rhyming verse (see, e.g., Lord 1960, 65) - whose frequent end-stopped lines mean that each one can be read as a syntactical unit-, such examples are again not difficult to find in any of these four romances.

As the oldest English romance, it is unsurprising that Horn's verse structure is evidently the most archaic. Although the four-beat meter of its rhyming couplets has sometimes been likened to Anglo-Norman octosyllabic verse, Horn's lines lack the syllabic regularity of true tetrameters, and should 
probably be more readily likened to Old English verse, with rhyme substituted for alliteration (Barron 1987, 223). Since each line is usually a complete syntactical unit with either no enjambment or only unperiodic enjambment, Horn makes frequent use of parataxis, with independent clauses following one another sequentially, either asyndetically or syndetically (usually with 'and'), and polysyndeton is also frequent. When used, even subordinate clauses (introduced by 'that') follow their main clauses as additions rather than being embedded in them, as in the following illustrative example:

Twelf feren be hadde

That he alle with bim ladde,

Alle riche mannes sones,

And alle bi were faire gomes,

With bim for to pleie,

And mest be luvede tweie;

That on bim bet Hathulf child,

And that other Fikenild.

Athulf was the beste,

And Fikenylde the werste. (21-30)
He had twelve companions,

all of whom he led with him,

all rich men's sons,

and they were all good fellows,

[suitable] to play with him;

and he loved two most:

the one called himself child Athulf, and the other Fikenhild.

Athulf was the best,

and Fikenhild the worst.

Likewise, Havelok, whose only complete manuscript copy follows King Horn in Bodleian Library MS Laud Misc. 108 - notably in the same hand, though a purer form of the Norfolk dialect (McIntosh 36) - resembles its predecessor in both its rhyming couplets and syntactical arrangement. It has the same sequential organisation of independent and dependent clauses, with subordination following main clauses as additions where they occur:

But bwan his wundes weren shewed,

And a leche havede knawed

That he hem mouthe ful wel hele,

Wel make bim gange and ful wel mele, And wel a palefrey bistride,

And wel upon a stede ride,

Tho let Ubbe al his care

And al his sorwe over fare,

And seyde, 'Cum now forth with me,

And Goldeboru, thi wif, with thee,

And thine serjaunz alle thre,

For now wile I youre warant be'. (2056-67)
But when his wounds were shown, and a doctor made known, that he might full well heal him, well make him walk and full well talk, and well mount a palfrey, and ride well upon a steed, then Ubbe put aside all his concern and overcame all his sorrow, and said, 'Come forth with me now, any your wife, Goldborough, with you, and all three of your sergeants,

For I will now be your guarantor'. 
In this, the four-beat rhyming couplets of Horn and Havelok actually provide a form that permits a syntactic arrangement of semantic thought not unlike that found in Zogić and Makić's orally composed pentameters - which formed a significant basis of Lord's own analysis of the oral formula (1960, 60-67) though as shall be seen, this quality seems to diminish over time.

Innovative Athelston, for example, employs the more sophisticated twelveline tail-rhyme stanza that latterly became particularly associated with Middle English verse romance. Its shorter b-lines, which occur every third line with only three stresses, are ideal for subordination, but here too parataxis is as frequent as hypotaxis:

'For yiff that I may my brother borwe

And bryngen bym out off mekyl sorwe,

Thou may make glad chere;

And thy warysoun I schal thee geve,

And God bave grauntyd thee to leve

Unto an bundryd yere'. (399-404)

The goode eerl soone was hent

And feteryd faste, verrayment,

And bys sones twoo.

Ful lowde the countasse gan to crye,

And sayde, 'Goode brothir, mercy!'. (651-53)
'For if I may save my brother and bring him out of great sorrow, you may make glad cheer; and I shall give you your reward Even if God has granted you a hundred years to live'.

The good earl was soon seized and fettered fast, truly, and his two sons. The countess began to cry very loudly and said, 'Good brother, mercy!'.

Finally, Gamelyn, the most recent romance, deceptively has what seems to be the most archaic verse structure of all. Much as in Old English verse, every line consists of two double-beat hemistichs divided by a medial caesura. This results in the possibility of each hemistich forming a complete syntactic unit, almost doubling the possibility of addition occurring, as demonstrated by frequent use of parataxis not only from line to line, but also across the caesura:

Than seide Gamelyn to the justise,

'Now is thi power don, the most nedes rise;

Thow hast yeven domes that bene evel dight,

I will sitten in thi sete

and dressen bem aright'.

The justice satte stille and roos not anon;

And Gamelyn cleved bis chekebon;
Then Gamelyn said to the justice,

Now your power is finished, you must need rise;

You have given judgments that are badly judged.

I will sit in your seat

and redress them correctly'.

The justice sat still, and did not rise at once;

And Gamelyn cleaved his cheekbone; 
Gamelyn toke bim in bis armes

and no more spake,

But threwe bym over the barre

and his arme brake. (841-48)
Gamelyn took him in his arms

and spoke no more,

But threw him over the bar, and broke his arm.

Here, parataxis is absent only across the caesura in the first and sixth of these eight lines, and while this might be characteristic of oral processing, it is curiously not entirely characteristic of the Anglo-Saxon verse the construction superficially resembles. Like Latin, Old English was a synthetic language that did not depend upon the same sort of additive analytic constructions required by Middle and modern English. While Old English was capable of employing appositive phases in sequential hemistichs for effect, as is done here, it could just as well split elements of a unified grammatical phrase into different lines or half-lines, which Gamelyn never does, and cannot do. Indeed, the resemblance to Old English verse is arguably intentional rather than inherent. Although Gamelyn's couplets superficially resemble the long lines of the fourteenth-century's so-called alliterative 'Revival' - directly indebted to Old English verse, and fostered most strongly across the country in the rural northwest - it replaces the characterizing alliteration with the rhyme especially popular in the southeast. The whole structure therefore seems contrived to look more rustic and authentic, and perhaps consequentially, so does its use of folksy formulaic expressions.

Gamelyn is not unique in this respect, however, as all these romances are additive rather than subordinate, but this quality is more present here than in Athelston, and less affected in Horn and Havelok. It therefore seems that in Gamelyn not only the use of formulae, but the very verse structure itself is anachronistically archaic, an aspect that also could be considered skeuomorphic if one believes the vintage form, perfectly adapted to Old English prosody, is no longer as well suited to Middle English's evolved suprasegmental permutations.

\section{II.1 (i): Narrative is Empathetic and Participatory}

Ong's seventh characteristic of orality, and perhaps the most interesting one for the purposes of this study, is that such narratives are 'empathetic and participatory rather than objectively distanced' (45). This means that the narrator becomes an active participant in the narrative, interacting directly with the audience. This is exactly what is found in the romances' first-person exhortative openings, recapitulative signposting, and even prayerful closings. 
The exhortative openings, in which the narrative voice addresses the audience directly, serve the function of calling an audience together, clearly a remnant of actual recitations. Horn begins with a bardic voice saying he will sing the audience a song:

Alle beon be blithe

That to my song lythe!

A sang ich schal you singe. (1-3)
They are all happy

Who listen to my song!

I shall sing you a song.

Havelok likewise calls an audience to listen, naming its members, and even requesting a drink:

Herkneth to me, gode men -

Wives, maydnes, and alle men -

Of a tale that ich you wile telle... (1-3)

That ye mowen now yhere, And the tale you mowen ylere, At the biginnig of ure tale, Fil me a cuppe of ful god ale;

And wile drinken, her I spelle. (11-16)
Hearken to me, good men, wives, maidens, and all men, of a tale that I will tell you...

That you may now hear, any [that] you may learn the tale, at the beginning of our tale, Fill me a cup of good ale, and [I] will drink while I recount.

Athelston also asks the audience to listen, with a first-person narrator saying he will tell them a story:

Lystnes, lordyngys, that ben hende,

Of falsnesse, bou it wil ende

A man that ledes hym therin.

Of foure weddyd bretheryn I wole yow tell. (7-10)
Listen, Lords, that are gracious, Of falseness! How it will end a man who leads himself therein.

Of four wedded brothers I will tell you...

And Gamelyn likewise admonishes the audience to listen three times in the first line:

Lithes and listneth and harkeneth aright, And ye shul here of a doughty knyght. (1-2)
Hear and listen and hearken aright, and you shall hear of a doughty knight.

While such stylistic exhortations certainly mimic the aesthetics of oral composition - notably in Havelok's very true-to-life request for a drink even if they were read aloud to a living audience, these fixed written texts are decidedly not spontaneous, orally-composed performances. Havelok's compositor even admits as much in his closing, when he lets slip that he 
'kept awake many a night' (2999) to compose his geste (2984), defying Lord's axiom that 'oral epic' is composed 'not [for] a general but a specific moment of performance' (31). At best, these renditions are nostalgic imitations of orality - skeuomorphs - which even a medieval audience would essentially have recognized as acts of Aristotelian mimesis rather than spontaneous creation.

Such first-person address then continues to pepper the bodies of the romances, signposting episodic events, though, interestingly, they are less prevalent in the earlier romances than the latter. Gamelyn, for example, recycles its introductory exhortation, 'Hear and listen and hearken', to signal changes in episodic development so effectively that modern editors systematically use the tag to divide the poem into six fitts, each focusing on a different episode, although such divisions are nowhere marked in the manuscripts.

Fitt 2:

Lytheneth, and listeneth, and boldeth your tonge, And ye shul bere talking of Gamelyn the yonge. (169-70)

Hear and listen, and hold your tongue, and you shall hear a talking of Gamelyn the young.

Fitt 3:

Now lithenes and listneth

both yonge and olde,

And ye schul here gamen

of Gamelyn the bolde. (287-88)
Now hear and listen, both young and old, and you shall hear sport of Gamelyn the bold.

Fitt 4:

Lithen and listen and bolde your tunge,

And ye shal bere game

of Gamelyn the yonge;

Harkeneth, lordingges and listeneth aright... (339-40)

Fitt 5:

Now lithen and listen

so God geve you good fyne!

And ye shul here good game

of yonge Gamelyne. (546-47)
Hear and listen and hold your tongue, and you shall hear sport of Gamelyn the young; Hearken, lords, and listen aright.

Now hear and listen, may God give you a good end! And you shall hear good sport of young Gamelyn. 
Fitt 6:

Litheneth, and listeneth and bolde you stille, Hear and listen and hold yourself still, And ye shul bere bow Gamelyn

bad al bis wille. (765-66) and you shall hear how Gamelyn had his desire.

Athelston's narrative voice does much the same in regulating the narrative flow, insisting on the 'speaker's' personal knowledge of the veracity of the story being told:

Of foure weddyd bretheryn I wole yow tell. (10) I will tell you of four wedded brothers.

And, as the story telles me... (19)

And, as the story tells me...

Sertaynly, as I yow telle... (276)

Certainly, as I tell you...

He rod in Londone, as I yow telle. (352)

He rode to London, as I tell you.

In romaunce as we rede,

In romance as we read,

Sertaynly, as I yow telle... (383-84)

Certainly, as I tell you...

A messanger was afftyr sent

A messenger was sent after

To speke with the kyng.

to speak with the king.

I wene be bar bis owne name... (182-84)

I believe he bore his [the king's] own name...

But yit the qwene, as ye schole bere... (297) But yet the queen, as you shall hear...

Havelok's narrative voice likewise insists that he 'knows' details about his story to be true:

I wot fif bundred sithes and five... (213) I know a hundred and five times

In that time a man that bore

In that time, a man that bore,

Wel fifty pund, I wot, or more... (45-46) well fifty pounds or more [of gold]...

A lof he bet, I woth, and more... (654)

A loaf he ate, I know, and more

and consistently encapsulates episodes between phrases such as:

Here I schal biginnen a rym. (21)

Of Goldeboru shul we now laten. (328)

Say we now forth in bure spelle! (338)

Of Grim bidde ich namore spelle. (2530)
Here I shall begin a poem

We shall now leave off about Goldborough

We now tell forth in our story!

I wish to tell no more about Grim. 
Horn, the earliest romance, employs direct address much more sparingly than the others, however, using it only to signal the end of the introduction and the beginning of the tale proper with: Also ich you telle may ('As I may tell you' [32]). Only at the end of the tale does the narration again use first-person, addressing a short prayer to the audience:
Her endeth the tale of Horn
Here ends the tale of Horn,
That fair was and noght unorn. who was fair and not ugly.
Make we us glade evre among, Let us make ourselves glad together,
For thus bim endeth Hornes song.
Jesus, that is of bevene king, for thus Horn's song ends itself.
Yeve us alle His swete blessing. (1539-44) Jesus, that is king of heaven, give us all His sweet blessing.

As Havelok, Athelston and Gamelyn demonstrate, such closure is as common to the end of English romances as 'they lived happily ever after' is to fairy tales:

Fortbi ich wolde biseken you

That haven herd the rim nu,

That ilke of you, with gode wille,

Saye a Pater Noster stille

For him that haveth the rym maked, And ther-fore fele nibtes waked, That fesu Crist bis soule bringe Biforn bis Fader at bis endinge. (Havelok 2994-3001)

Now fesu, that is Hevene-kyng,

Leve nevere traytour have betere endyng,

But swych dome for to dye. (Athelston 810-12)

And sithen wedded Gamelyn a wif good and faire;

They lyved togidere the while that Crist wolde, And sithen was Gamelyn graven under molde. And so shull we alle may ther no man fle:

God bring us to that joye that ever shal be! (Gamelyn 894-98)
I would therefore beseech you who have now heard this rhyme, that each of you, with good will, say a quiet Lord's Prayer for him who has made the rhyme, (and therefore stayed awake many nights) that Jesus Christ bring his soul before his father at his death.

Now Jesus, that is king of Heaven, Never let a traitor have a better ending, But [have] such judgement to die.

And then Gamelyn wed a good and fair wife; they lived together while Christ wanted it, and then Gamelyn was buried under the earth. And so shall we all; no man may flee from that: God, bring us to that joy that shall be forever!

Despite the compositor of Havelok admitting that he stayed up many nights to write the tale (2998-99), these instances of direct address are unquestionably the feature that immediately strikes even the casual reader as intrinsically oral. Not 
only do they clearly function to signpost the text in a manner that would be familiar to audiences in primarily oral cultures listening to orally composed 'epos' or 'voicings' that were 'rhapsodized' together by oral performers, but they bind narrator, audience and character together to such an extent that, in some respects, 'in the sensibility of the narrator and his audience, the hero of the oral performance assimilate[s] into the oral world even the transcribers who are de-oralizing it into text' (Ong 46). This more than anything reminds readers that even if these tales were written down, they were still framed as oral recitations, suggesting to some that they were 'probably' performed (Quinn 1-5), or 'sung, or chanted, or recited' (Hall 33). Some early scholars even theorized that manuscript variation in different versions of opening exhortations suggests that the originals were not even written down at all (Allen 33), thus corresponding to Lord's criterion of the formula being composed for a specific, rather than a general, occasion.

\section{Part it.2: Assimilation of the Literate by the Supposedly Oral}

The simple fact that all of these romances allude to literacy, however, precludes any of them being the product of a primary oral culture untouched by writing. Interestingly, the evidence for this is weakest in Gamelyn, perhaps simply because its late date makes writing expected rather than remarkable. Its only direct references to the written word are when Gamelyn 'swore by God's book' (91), and when his father summons the local lords to his deathbed 'by letters' (19). Despite this, and unlike messengers in the other tales, it is implied that the rider sent to Gamelyn's faithful brother, Sir Ote, delivered his message orally - as in days of yore - when he: tolde bim altogidere - bow Gamelyn was dight ('told him altogether how Gamelyn was treated' [726]). The romance also pointedly emphasises that Gamelyn's dying father makes an orally declared nuncupative will dividing his estate between all three sons in defiance of any previous will or current statutes that would prefer the eldest over the youngest (53-64). But Gamelyn's society is more than simply literate, it is actually dependent upon writing, a point the audience would recognize in the legal proceedings of having him declared an outlaw (705-06), his release on bail by surety to his brother (739-42), and the various processes of the sheriff's court and court of delivery, all of which were codified procedures by the time the text was written.

The earlier romances, on the other hand, throw writing into prominence, associating it with nobility, authority and authenticity. Atbelston, for example, mentions letters eleven times, and its very plot is constructed around deception 
through letter writing, a point emphasized nearly a dozen times. ${ }^{24}$ The romance furthermore claims itself to be an accurate account of a story 'we find written in books' (21), and repeatedly insists in formulaic expression that it is being told just 'as we read in romance' $(383,569,623,779)$. The earlier Havelok likewise mentions 'reading romances from the book' (2327), and calls itself a gest (2984). It also makes effective use of writing in advancing its plot: the dying King Athlelwold summons his vassals by writs (136-37); Ubbe sends writs to summon the Danes to pay homage to Havelok (2274-75); and a sign with 'letters' detailing Godrich's crimes is hung on his body when he is executed (2476-87). Even the hero of the oldest romance, Horn, sends writs throughout Ireland to recruit troops for his return to Westernesse (1011), an endeavour which is itself the result of having received one of the many letters Rymenhild dictated - but, tellingly, did not actually write - and sent far and wide to find him (938-44).

\section{PART II: CONCLUSION}

The brief but prominent references to reading and writing in Horn portray literacy as an exclusively noble and almost mystical talent. Only Horn and his faithful friend Athulf, to whom Rymenhild dictates her letters, are able to read and write, a skill that evidently the messenger himself has not mastered. Like magic charms, these missives find their intended recipient after a seven-year absence, warning Horn of jeopardy and calling him back as effectively as enchanted tokens of recognition. In Havelok and Atbelston, writing is a less mysterious art, but still a noble one. Literacy confers or confirms status, being effectively used to summon vassals, and affectedly used by kings, earls, clerics and countesses to exchange information amongst themselves. One presumes that such dignified associations would appeal to the 'newly-literate and uncritical popular audience (a reading audience)' for whom, it has been supposed, the romances of the Auchinleck manuscript - produced after Havelok but before Athelston - were fashioned by 'hack writers' in a London bookshop of the 1330s (Wittig 250; Hibbard Loomis 1942: 608-24). By the time Gamelyn was written, however, such immodest flaunting of what must by then have come to be seen as little more than the practical trade skills of such 'professional commercial writers' had evidently become unfashionable (Gibbs $25)$, resulting in the gentry personalities inhabiting that romance eagerly

24. Lines 14, 187, 193, 203, 206, 224, 299, 303, 364, 366, 715. 
embracing good old-fashioned orality in delivering messages and declaring wills aloud rather than in writing.

This nostalgia for old-school orality in the face of changes wrought by writing also seems to play a part in the proliferation of formulaic expression starting with Havelok. They are used briefly but relatively effectively in Horn, seen to exhibit the most hallmarks of orally-based thinking in its deep structures, seamlessly linking together material relevant to the plot, or nuancing that material with pertinent connotations. But the more that subconscious modes of literate thinking render such stylized linguistic performances irrelevant to the organization of deep-structure thought, the more they are consciously employed in surface-structure verbal pattering. As has been seen, in later romances these expressions become more cumbersome than concise, and are used excessively rather than economically. Such frequency and verbosity suggest that these contrived formulaic expressions are no longer even intended to anchor information essential to the plot, since they now actively distract from it. They become a focus of attention themselves, leading Ananya Kabir to declare of Havelok that:

its orality is as much a deliberate literary construct as its so-called realism. Its ostensibly oral features of thematic and lexical formulaicity not only appear too meticulously assembled to be the unplanned residue of an ebbing oral tradition, but also betray, in their very excess, an anxiety about orality and literacy as competing technologies of power and social control. (20)

In other words, in respect to its self-declared oral provenance, Havelok 'doth protest too much'. But this is as true of the later Atbelston and Gamelyn as it is of Havelok, as is Kabir's observation that such 'oral self-fashioning' is perhaps better evaluated as 'manifestations of a feigned orality' rather than true residual orality itself (20).

\section{General Conclusion: Feigned Orality as Literary Skeuomorphs}

It is this 'feigned orality' that has generally been vaunted as 'secondary orality' in transitional texts, or as Jesse Gellrich puts it, 'orality [which] persists in "residual" form, and [whose] principal channel of expression is the written word itself' (3). But the manifestations of this type of orality in the Middle English verse romances actually differ from classical oral-formulaic language 
of the Parry-Lord variety as much as the early New High German füngeres Hildebrandslied differs from the traditional Germanic oral poetry of the ninthcentury Älteres Hildebrandslied, which, as Miguel Ayerbe notes, 'changes from an oral to a written form' in which 'the way oral-formulaic features disappear without leaving almost any trace' (1345). Thus, while it might be true that the origins of these features in the medieval English romances lie in a distant tradition of primary orality - which requires functional formulae as an essential element for the organisation and expression of orally-based thought - as early as the second romance, Havelok, there is a proliferation of exaggerated formulaic expressions, whose resemblance to true formula of the purely oral tradition is as uncanny as queens of drag are to those of beauty. Though they deliberately emulate oral formulae of the original style, these formulaic expressions are no longer true representations of the way orally-based noetic processes arrange information. Indeed, given their complexity, frequency and variation, one can only imagine that the initial elaboration and implementation of such highly stylized formulaic expressions was tedious and timeconsuming, as Havelok's compositor admits. Indeed, rather than serving 'the singer in the rapid composition of his tale' (30) - which, according to Lord, is the essential function of a formula - they are instead useful primarily to the audience, the very concept against which Parry's early reassessment of such 'stock epithets', 'stereotyped phrases' and 'clichés' in Homer was formulated (Lord 30, referencing Parry 1928).

In this manifestation, formulaic expressions were no longer functional attributes that facilitated the telling or even the understanding of a tale; indeed, Wittig astutely notes that the 'redundant style' of these 'characteristic features' actually represent 'a highly disfunctional [sic] aspect of the narrative form, which impedes the audience's appreciation and understanding of the poem rather than furthers it' (251; emphasis original). But at some point between the early-thirteenth-century completion of Horn and the late-thirteenth-century penning of Havelok, such carefully crafted embellishments evidently came to be admired nevertheless, presumably for reasons more sentimental or aesthetic than practical. Indeed, after Havelok it seems that they even came to be seen as indispensable, for rather than falling into desuetude when it appears that literate-minded compositors began having difficulty artistically producing them mimetically, romancers resorted to copying tirades of formulaic lines directly from one romance to the other, ${ }^{25}$ apparently in order to meet audience demands for a form that might have been admired because of, rather than simply 
in spite of, its irrelevance or impracticality. In this, they typify the way in which 'audience expectations can help fix themes and formulas', causing 'narrators [to] narrate what audiences call for or will tolerate' (Ong 66).

Such painstaking initial reproduction and then sustained aping of essentially obsolete features as a flourish rather than an indispensable element of the architecture of medieval romance allows them to be likened to the aforementioned skeuomorphs of Classical Greek architecture, in that they are vestigial attributes, which are artificially reproduced for fundamentally aesthetic reasons, embellishing a structure that emulates an archetype where those attributes had been essential. Like the mutules, modillions, triglyphs and guttae of Doric architecture - in which the functional wooden beam ends and six wooden pegs that secured them on archaic Greek temples built of timber were impractically and inefficiently replicated in stone - they 'are deliberately employed to make the new look comfortably old and familiar, or are simply habits too deeply ingrained to wash away' (Paulos 53).

Indeed, it is tedious and redundant to re-create such obsolete features, for neither the guttae's fortuitous quality of whisking water away from a building's façade, nor the formulae's incidental quality of facilitating occasional oral deliveries of a written text (Wittig 27), actually expediate the creation of the works as a whole to which they are mere appendages in any meaningful way. Like buttons on the sleeve of a store-bought vest, they represent added work for the producer that is of no practical value to him or the consumer, but via its contrived resemblance to an archetype, their reproduction lends the product the cultural authenticity required for consumption. In this, they are undeniably skeuomorphic, and just as the simple Doric skeuomorphs evolved into more complex forms once they were freed from the constraints their original functional purpose imposed, formulaic expressions of oral traditionalism become increasingly more elaborate when liberated from the constraints of primary orality's need for concise, functional formulae. Thus, rather than representing any actual manifestation of orally-based thought in the writers who produced them, they exist primarily as derivative skeuomorphic artifacts of orally-based expression in works composed chirographically by primarily literate minds.

25. The classic example of this is the late-fourteenth-century Sir Orfeo, which lifts 22 of its 24 opening lines directly from the early-fourteenth-century Lay le Frayn, 18 of them verbatim with nearly identical orthography. 


\section{REFERENCES}

Aertsen, Henk. "Havelok the Dane: A Non-Courtly Romance". Companion to Early Middle English Literature. Eds. Henk Aertsen and N. H. G. E. Veldhoen. Amsterdam: vU University Press, 1995. 29-50.

Allen, Rosamund. "Date and Provenance of King Horn: Some Interim Reassessments". Medieval English Studies Presented to George Kane. Eds. Edward Donald Kennedy, Ronald Waldron and Joseph S. Wittig. Suffolk: St. Edmundsburg Press, 1988, 99-126.

Ayerbe, Miguel. "La evolución de un mismo cantar heroico desde su transmisión oral a su transmisión escrita: el caso del Cantar de Hildebrando alemán". Transitional Texts: Drifting between the Oral and the Written. Eds. S. Gintsburg, J. Ford \& A. Barandiaran. Special issue of Rilce 36.4 (2020): 1344-70.

Barron, William R. J. "The Penalties for Treason in Medieval Life and Literature". Fournal of Medieval History 7 (1981): 187-202.

Barron, William R. J. English Medieval Romance. London: Longman, 1987.

Battles, Dominique. "Reconquering England for the English in Havelok the Dane". The Chaucer Review 47.2 (2012): 187-205.

Battles, Dominique. Cultural Differences and Medieval Culture in Middle English Romance: Normans and Saxons. New York: Routledge, 2013.

Baugh, Albert C. "The Authorship of the Middle English Romances". Bulletin of the Modern Humanities Research Association 22 (1950): 13-28.

Baugh, Albert C. "The Middle English Romance: Some Questions of Creation, Presentation and Preservation". Speculum 42.1 (1967): 1-31.

Bellamy, John G. The Law of Treason in England in the Later Middle Ages. Cambridge: Cambridge UP, 1970.

Bradbury, Nancy Mason. "The Traditional Origins of Havelok the Dane". Studies in Pbilology 90.2 (1993): 115-42.

Bradbury, Nancy Mason. Writing Aloud: Storytelling in Late Medieval England. Urbana: University of Illinois Press, 1998.

Bradbury, Nancy Mason. "Gamelyn". Heroes and Anti-Heroes in Medieval Romance. Ed. Neil Cartlidge. Cambridge: D. S. Brewer, 2012. 129-44.

Cantor, Norman. The Civilisation of the Middle Ages. 1963. New York: Harper Collins, 1994.

Carpenter, Christine. "Law, Justice, and Landowners in Medieval England". Law and History Review 1.2 (1983): 205-37. 
Cartwright, Mark. "The Weapons of an English Medieval Knight". Ancient History Encyclopedia, June 6, 2018. https://www.ancient.eu/article/1238/ the-weapons-of-an-english-medieval-knight/.

Chomsky, Noam. Current Issues in Linguistic Theory. The Hague: Morton, 1964. Clanchy, Michael T. From Memory to Written Record. 3rd ed. Oxford: WileyBlackwell, 2013.

Crane, Susan. Insular Romance: Politics, Faith and Culture in Anglo-Norman and Middle English Culture. Berkeley: University of California Press, 1986.

Crosby, Ruth. "Oral Delivery in the Middle Ages". Speculum 11.1 (1936): 88110.

Crosby, Ruth. "Chaucer and the Custom of Oral Delivery". Speculum 13.4 (1938): 413-32.

Delany, Sheila, and Vahan Ishkanian. "Theocratic and Contractual Kingship in Havelok the Dane". Zeitschrift für Anglistik und Amerikanistik 22 (1974): 290-302.

Diamond, Robert. "Diction of the Signed Poems of Cynewulf". Philological Quarterly 38 (1959): 228-41.

Duggan, Joseph. The Song of Roland: Formulaic Style and Poetic Craft. Berkeley: University of California Press, 1973.

Dunn, Charles W. "Romances Derived from English Legend". Manual of Writings in Middle English, 1050-1500, vol. 1: Romances. Ed. J. B. Severs. New Haven: Connecticut Academy of Arts and Science, 1967. 17-37.

Eckert, Kenneth. "He Clothed and Fedde Him Evell': Narrative and Thematic 'Vulnerability' in Gamelyn". Medieval and Early Modern English Studies 23.1 (2015): 131-46.

Erman, Britt, and Beatrice Warren. "The Idiom Principle and the Open Choice Principle”. Interdisciplinary fournal for the Study of Discourse 20.1 (2000): 29-62.

Field, Rosalind. "The Material and the Problem". A Companion to Medieval Popular Romance. Eds. Racula L. Radulescu and Cory James Rushton. Cambridge: Boydell and Brewer, 2009. 9-30.

Fillmore, Charles J. "Frame Semantics". Linguistics in the Morning Calm: Select Papers from SICOL-1981. Ed. Linguistic Society of Korea. Seoul: Hanshin, 1982. 111-37.

Finnegan, Ruth. "'Transitional' Texts across the world - what are they?". Transitional Texts: Drifting between the Oral and the Written. Eds. S. Gintsburg, J. Ford \& A. Barandiaran. Special issue of Rilce 36.4 (2020): 1251-72. 
Foley, John Miles. The Singer of Tales in Performance. Bloomington: Indiana UP, 1995.

Ford, John. "Towards a New Understanding of Formulae: Prototypes and the Mental Template". Neuphilologische Mitteilungen 103.2 (2002): 205-26.

Ford, John. "Travel in the Middle English Matter of England Romances, and the Evolutionary Portrayal of Horses and Horsemanship". Horses Across the Medieval World. Eds. Anastasija Ropa and Timothy Dawson. Leiden: Brill. Forthcoming.

Gellrich, Jesse. Discourse and Dominion in the Fourteenth Century. Princeton: Princeton UP, 1995.

Gibbs, A. C. Middle English Romances. Evanston, IL: Northwestern UP, 1966.

Giles, John Allen. The Life and Times of Alfred the Great. 2nd ed. Oxford: W. Baxter, 1854.

Gintsburg, Sarali. Formulaicity in fbala Poetry. Tilburg: Prisma, 2014.

Ginstburg, Sarali. "A Cognitive Approach to Traditional Oral Poetry: Frames and Scripts in the Jebli Ayyu". AAM 26 (2019): 1-23.

Hall, Joseph, ed. King Horn. Oxford: Oxford UP, 1901.

Hanning, Robert W. "Havelok the Dane: Structure, Symbols, Meaning”. Studies in Philology 64 (1967): 586-605.

Harrill, Claire. "Saracens and Racial Otherness in Middle English Romance". Discovering Literature: Medieval. London: British Library, 2018. Web. $<$ https://www.bl.uk/medieval-literature/articles/saracens-and-racialotherness-in-middle-english-romance $>$.

Hawes, Janice. "Saracens in Middle English Romance". Islam and Postcolonial Discourse: Purity and Hybridity. Eds. Esra Mirze Santesso and James McClung. London: Routledge, 2017. 15-30.

Herzman, Ronald B., Graham Drake and Eve Salisbury, eds. Four Romances of England: King Horn, Havelok the Dane, Bevis of Hampton, Athelston. Kalamazoo, MI: Medieval Institute Publications, 1999.

Hibbard Loomis, Laura A. "Athelston, a Westminster Legend". PMLA 36.2 (1921): 223-44.

Hibbard Loomis, Laura A. "The Auchinleck Manuscript and a Possible London Bookshop of 1330-40”. PMLA 57.3 (1942): 595-627.

Kabir, Ananya J. "Forging an Oral Style? Havelok and the Fiction of Orality". Studies in Philology 98.1 (2001): 18-48.

Kaeuper, Richard W. "An Historian's Reading of The Tale of Gamelyn”. Medium Avum 52.1 (1983): 51-62. 
Kay, Sarah, ed. Raoul de Cambrai. Oxford: Clarendon Press, 1992.

Knight, Stephen K., and Thomas H. Ohlgren. Robin Hood and Other Outlaw Tales. Kalamazoo, MI: Medieval Institute Publications, 1997.

Lambdin, Robert Thomas, and Laura Cooner Lambdin. Encylopedia of Medieval Literature. Westport, CT: Greenwood Press, 2000.

Lindner, F. "The Tale of Gamelyn”. Englische Studien 2 (1879): 94-114, 321-43. Lord, Albert Bates. The Singer of Tales. 1960. 2nd ed. Eds. Stephen Mitchell and Gregory Nagy. Cambridge, MA: Harvard UP, 2003.

Lucas, Angela M. "Fair Play, Justice and the Law in The Tale of Gamelyn". The Maynooth Review 5.2 (1979): 45-49.

Ludwikowska, Joanna. "(Breaking) the Law: Social Control, Self-Help and Violence in The Tale of Gamelyn". Studia Anglica Posnaniensia 48.4 (2013): 63-77.

McIntosh, Angus. "The Language of the Extant versions of Havelok the Dane". Medium Avum 45.1 (1976): 36-49.

MED: Middle English Dictionary. Eds. Robert E. Lewis et al. Ann Arbor: University of Michigan Press, 1952-2001. [Online edition in Middle English Compendium. Eds. Frances McSparran et al. Ann Arbor: University of Michigan Library, 2000-2018] <http://quod.lib.umich.edu/m/middleenglish-dictionary/>. Accessed 13 May 2020.

Menuge, Noël James. Medieval English Wardship in Romance and Law. Cambridge: Boydell and Brewer, 2001.

Moon, R. "Vocabulary Connections: Multi-Word Items in English". Vocabulary: Description, Acquisition and Pedagogy. Eds. N. Schmitt and M. McCarthy. Cambridge: Cambridge UP, 1997.

Murray, Alan V. "The Livonian Rhymed Chronicle as a Transitional Text: Formulaic Language in a Middle High German Verse Chronicle". Transitional Texts: Drifting between the Oral and the Written. Eds. S. Gintsburg, J. Ford \& A. Barandiaran. Special issue of Rilce 36.4 (2020): 1324-43.

Ong, Walter J. Orality and Literacy. 1982. New York: Routledge, 2002.

Parry, Milman. L'Épithète traditionnelle dans Homère: essai sur un problème de style homérique. Paris: Les Belles Lettres, 1928.

Parry, Milman. "Studies in the Epic Technique of Oral Verse-Making, I: Homer and Homeric Style". Harvard Studies in Classical Pbilology 41 (1930): 73-148.

Paulos, Eric. "Affordance, Contextual Inquiry, and Conceptual Models". CS 160 (Spring 2016). University of California, Berkeley. 8 February 2016, 
53. <http://teaching.paulos.net/cs160_SP2016/lectures/cs160-sp16-06. pdf.>.

Pearsall, Derek. "The Development of Middle English Romance". 1965.

Studies in Medieval English Romance: Some New Approaches. Ed. Derek Brewer. Cambridge: D. S. Brewer, 1988. 11-36.

Quinn, William A. Fongleur: A Modified Theory of Oral Improvisation and Its Effects on the Performance and Transmission of Middle English Romance. Washington, DC.: University Press of America, 1982.

Rouse, Robert Allen. The Idea of Anglo-Saxon England in Middle English Romance. Cambridge: Boydell and Brewer, 2005.

Rowe, Elizabeth Ashman. "The Female Body Politic and the Miscarriage of Justice in Athelston". Studies in the Age of Chaucer 17 (1995): 79-98.

Sands, Donald B., ed. Middle English Verse Romances. New York: Holt, Rinehart, and Winston, 1966.

Sartore, Melissa. Outlawry, Governance and Law in Medieval England. New York: Peter Lang, 2013.

Scattergood, John. "The Tale of Gamelyn: the Noble Robber as Provincial Hero". Readings in Medieval English Romance. Ed. Carol M. Meale. Cambridge: Boydell and Brewer, 1994. 159-94.

Schmitt, Norbert, and Ronald Carter. "Formulaic Sequences in Action: An Introduction". Formulaic Sequences: Acquisition, Processing, and Use. Ed. Norbert Schmitt. Amsterdam/Philadelphia: John Benjamins, 2004. 122.

Shannon, Edgar F. "Mediaeval Law in The Tale of Gamelyn". Speculum 26.3 (1951): 458-64.

Shippey, T. A. "The Tale of Gamelyn: Class Warfare and the Embarrassments of Genre". The Spirit of Medieval English Popular Romance. Eds. Ad Putter and Jane Gilbert. Longman: Harlow, 2000. 78-96.

Skeat, Walter W., ed. The Tale of Gamelyn: From the Harleian MS. No. 7334. Oxford: Clarendon Press, 1884.

Speed, Diane. "The Saracens of King Horn”. Speculum 65.3 (1990): 564-95.

Staines, David. "Havelok the Dane: A Thirteenth-Century Handbook for Princes". Speculum 51 (1976): 602-23.

Strickland, Matthew. War and Chivalry: The Conduct and Perception of War in England and Normandy 1066-1217. Cambridge: Cambridge UP, 1996.

Stuart, Christopher. "Havelok the Dane and Edward I in the 1290's". Studies in Pbilology 93 (1996): 349-64. 
Ten Harkel, Letty. "The Vikings and the Natives: Ethnic Identity in England and Normandy c. 1000 AD". The Medieval Chronicle IV. Ed. Erik Kooper. Amsterdam: Rodopi, 2006. 177-90.

Thiébaux, Marcelle. "The Mediaeval Chase". Speculum 42.2 (1967): 260-74.

Weiss, Judith. "Thomas and the Earl: Literary and Historical Contexts for the Romance of Horn". Tradition and Transformation in Medieval Romance. Ed. Rosalind Field. Woodbridge, Suffolk: Boydell \& Brewer, 1999.

Wittig, Susan. "Formulaic Style in the Middle English Romance". Neuphilologishe Mitteilungen 78.3 (1977): 250-55.

Young, Helen. "Athelston and English Law: Plantagenet Practice and AngloSaxon Precedent”. Paragon 22.1 (2005): 95-118. 